\title{
Neuroendocrine Regulation of Energy Metabolism Involving Different Types of Adipose Tissues
}

\author{
Qi Zhu ${ }^{1}$, Bradley J. Glazier ${ }^{1}$, Benjamin C. Hinkel ${ }^{1}$, Jingyi Cao ${ }^{1}$, Lin Liu ${ }^{2}$, Chun Liang ${ }^{2}$ and \\ Haifei Shi ${ }^{1, *}$ (i) \\ 1 Program of Physiology and Neuroscience, Department of Biology, Miami University, Oxford, OH 45056, \\ USA; zhuq2@miamioh.edu (Q.Z.); glazieb2@miamioh.edu (B.J.G.); hinkelbc@miamioh.edu (B.C.H.); \\ caoj2@miamioh.edu (J.C.) \\ 2 Program of Bioinformatics, Department of Biology, Miami University, Oxford, OH 45056, USA; \\ liul2@miamioh.edu (L.L.); liangc@miamioh.edu (C.L.) \\ * Correspondence: shih@miamioh.edu; Tel.: +1-513-529-3162
}

Received: 29 April 2019; Accepted: 29 May 2019; Published: 1 June 2019

\begin{abstract}
Despite tremendous research efforts to identify regulatory factors that control energy metabolism, the prevalence of obesity has been continuously rising, with nearly $40 \%$ of US adults being obese. Interactions between secretory factors from adipose tissues and the nervous system innervating adipose tissues play key roles in maintaining energy metabolism and promoting survival in response to metabolic challenges. It is currently accepted that there are three types of adipose tissues, white (WAT), brown (BAT), and beige (BeAT), all of which play essential roles in maintaining energy homeostasis. WAT mainly stores energy under positive energy balance, while it releases fuels under negative energy balance. Thermogenic BAT and BeAT dissipate energy as heat under cold exposure to maintain body temperature. Adipose tissues require neural and endocrine communication with the brain. A number of WAT adipokines and BAT batokines interact with the neural circuits extending from the brain to cooperatively regulate whole-body lipid metabolism and energy homeostasis. We review neuroanatomical, histological, genetic, and pharmacological studies in neuroendocrine regulation of adipose function, including lipid storage and mobilization of WAT, non-shivering thermogenesis of BAT, and browning of BeAT. Recent whole-tissue imaging and transcriptome analysis of differential gene expression in WAT and BAT yield promising findings to better understand the interaction between secretory factors and neural circuits, which represents a novel opportunity to tackle obesity.
\end{abstract}

Keywords: white adipose tissue; brown adipose tissue; beige adipose tissue; adipokines; batokines; sympathetic nervous system; innervation; denervation; thermogenesis; lipolysis; fatty acid oxidation; high-fat diet; RNA sequencing

\section{Introduction}

Maintaining energy homeostasis is imperative for health maintenance in any living organism, a process regulated by complicated neural circuits and secretory factors. The central nervous system (CNS) receives and integrates a variety of external stimuli from the environment such as diet and temperature, along with internal neural and chemical signals from peripheral tissues indicating energy status and storage. The CNS subsequently sends outward signals via the autonomic nervous system that directly contacts multiple tissues and organs to closely control metabolism and achieve the metabolic homeostasis (Figure 1). 


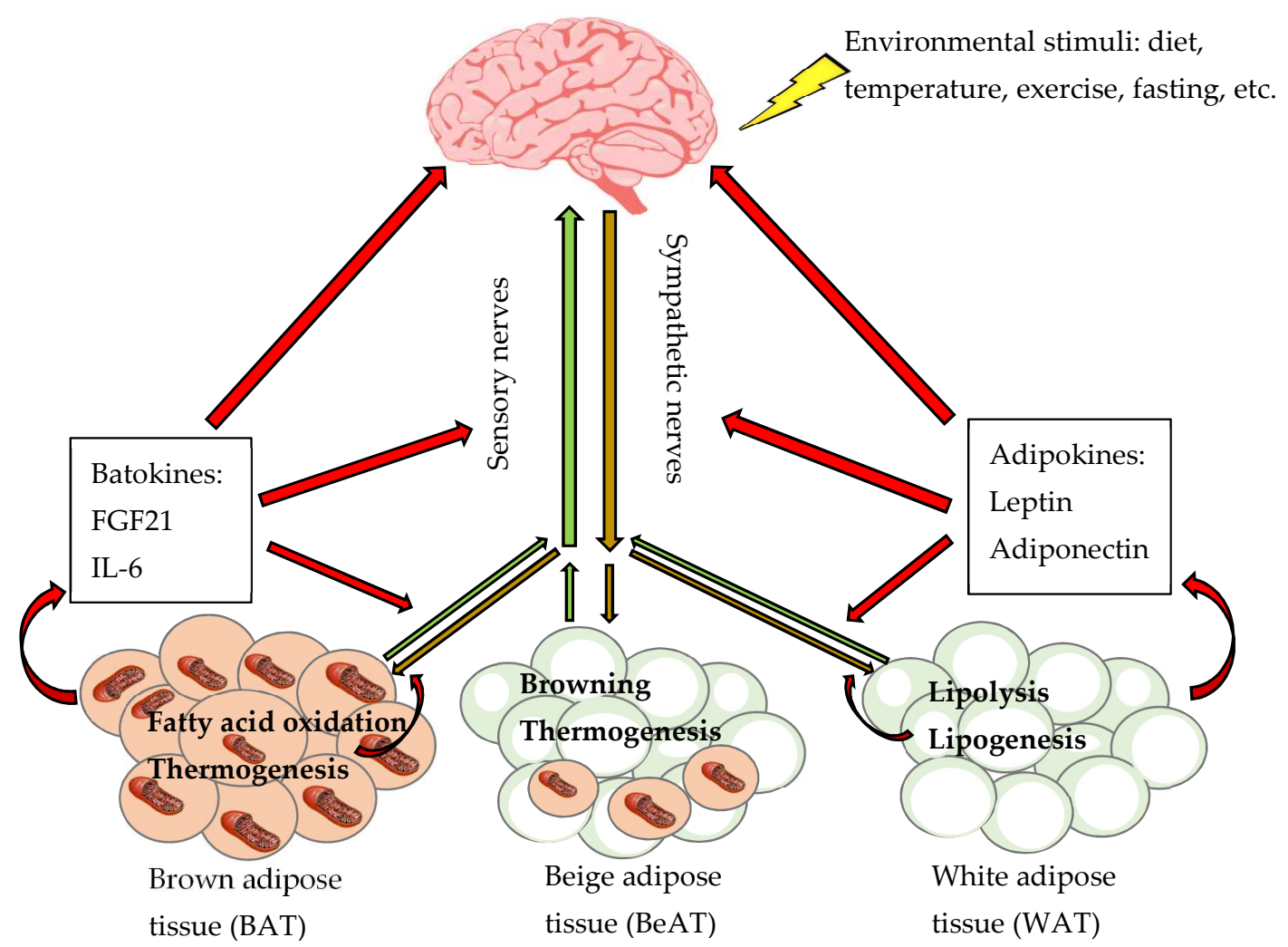

Figure 1. Neuroendocrine regulation of lipid metabolism at different types of adipose tissues. A two-way communication exists between the brain and white, brown and beige adipose tissues (WAT, BAT and BeAT, respectively) involving neural signals consisting of afferent sensory nerves (green arrows) and efferent sympathetic nerves (brown arrows), and endocrine signals (red arrows) consisting of WAT adipokines and BAT batokines. Environmental stimuli (i.e., diet, temperature, exercise, fasting) that change energy stores modulate sympathetic activity to regulate lipolysis, lipogenesis, and adipokine secretion at WAT; thermogenesis, fatty acid oxidation, and batokine secretion at BAT; and induction of BeAT and browning. A number of WAT adipokines (such as leptin and adiponectin) and BAT batokines (such as fibroblast growth factor 21 [FGF21] and interleukin 6 [IL-6]) interact with neural circuits to cooperatively regulate whole-body energy metabolism.

Adipose tissue is one of the primary sites of the regulation of lipid metabolism, which includes three metabolic processes: Lipogenesis involving cell proliferation and uptake of circulating free fatty acids; lipolysis involving hydrolysis of triglycerides into glycerol and free fatty acids; and fatty acid $\beta$-oxidation inside the mitochondria [1]. During negative energy balance when energy expenditure exceeds energy intake, such as during exercise or fasting, stored lipids are mobilized via lipolysis to release fatty acids and glycerol which are used by other tissues and organs [2]. During positive energy balance when energy intake exceeds energy expenditure, such as during feeding with a high-fat diet, extra calories are primarily stored as lipids that accumulate in adipose tissues via increased fatty acid uptake and de novo lipogenesis [3-6].

Chronic dysregulation of energy balance due to energy intake exceeding energy expenditure results in excess lipid storage in adipose tissues, leading to obesity. Currently, $39.8 \%$ of adults and $18.5 \%$ of children in United States have a BMI over 30 and are classified as obese [7]. A number of environmental factors in Western society, including calorie-dense diet, sedentary lifestyle, and stress collectively contribute to an imbalance of energy homeostasis and development of obesity [8]. Obesity is closely associated with the development of chronic diseases, such as type 2 diabetes, cardiovascular diseases, non-alcoholic hepatic steatosis, and some types of cancer, and thus it is a major health issue [9-11]. Because of the global increases in the incidence of obesity and its associated metabolic 
diseases, it is of great significance to understand mechanisms underlying the regulation of lipid metabolism in adipose tissues. Consequently, increasing attention has been placed on understanding the neuroendocrine regulation of adipose function as a regulatory mechanism of energy metabolism. While the innervation of adipose tissue was first reported in the 1890s, more recent advancements in imaging, tracing, and RNA sequencing have yielded new insight into the innervation of adipose tissue and its function. This has led to the discovery of a number of adipose secretory factors that interact with neural circuits extending from the brain to play important roles in regulating numerous processes in white, brown and beige adipose tissues (WAT, BAT, and BeAT, respectively), including lipid storage and mobilization of WAT, fatty acid oxidation and non-shivering thermogenesis of BAT, and browning of BeAT, which ultimately affect whole-body energy homeostasis.

Because a better understanding of the regulation of lipid metabolism at the level of adipose tissues may offer an innovative opportunity to tackle obesity, we aim to review advances in the understanding of regulation of adipose function at different types of adipose tissues by summarizing historic and recent studies using histological, imaging, genetic, and pharmacological approaches. In addition, we compare expression of some genes related to neuroendocrine regulation of lipid metabolism between WAT and BAT using recent RNA sequencing data obtained from different types of adipose tissues of either lean male mice fed a standard low-fat diet or obese male mice fed a high-fat diet for four weeks [12] (Table 1). Special emphasis is placed on results from genomic analysis of various types of adipose tissues as this helps to understand differences between WAT and BAT, clarify unsettled questions, and develop novel targets for better regulation of energy metabolism.

Table 1. Genes compared between white adipose tissue (WAT) and brown adipose tissue (BAT) of lean and obese male mice using RNA sequencing data.

\begin{tabular}{|c|c|c|c|c|c|}
\hline \multirow{2}{*}{ Gene Categories } & \multirow{2}{*}{ Genes } & \multicolumn{2}{|c|}{ WAT } & \multicolumn{2}{|c|}{ BAT } \\
\hline & & Lean & Obese & Lean & Obese \\
\hline thermogenesis & uncoupling protein 1 (Ucp1) & Low & Low & High & High \\
\hline \multirow{3}{*}{$\begin{array}{l}\text { Brown adipocyte } \\
\text { precursors }\end{array}$} & myogenic factor 6 (Myf6) & \multirow{2}{*}{ Low } & \multirow{2}{*}{ NS } & \multirow{2}{*}{ High } & \multirow{2}{*}{ NS - } \\
\hline & sarcoglycan gamma $(S g c g)$ & & & & \\
\hline & tropomyosin $\beta$ (Tpm2) & Low & Low & High & High - \\
\hline \multirow{2}{*}{ WAT adipokines } & leptin (Lep) & NS & High + & NS & low \\
\hline & adiponectin (Adipoq) & NS & High & NS & low \\
\hline \multirow{3}{*}{ BAT batokines } & interleukin 6 (Il6) & Low & Low & High & High \\
\hline & fibroblast growth factor 21 ( $F g f 21)$ & NS & NS & NS & NS \\
\hline & neuregulin $4(\mathrm{Nrg} 4)$ & NS & NS - & NS & NS \\
\hline $\begin{array}{l}\text { Sympathetic } \\
\text { nerve }\end{array}$ & tyrosine hydroxylase $(T h)$ & Low & NS/ND & High & NS \\
\hline Sensory nerve & calcitonin gene-related peptide (Calca) & NS & High & NS & Low \\
\hline $\begin{array}{l}\text { Parasympathetic } \\
\text { nerve }\end{array}$ & vesicular acetylcholine transporter $(\operatorname{Slc18a3)}$ & \multicolumn{4}{|c|}{ ND } \\
\hline Lipolysis & hormone-sensitive lipase (Lipe) & NS & High & NS & Low \\
\hline $\begin{array}{l}\text { Fatty acid } \\
\text { oxidation }\end{array}$ & carnitine palmitoyltransferase 1 (Cpt1b) & Low & Low & High & High + \\
\hline
\end{tabular}

Obese mice fed with a high-fat diet had three times of adiposity comparing to the lean mice fed with a low-fat diet for four weeks. Approximately 30 million of single-end sequencing reads were retrieved from each WAT and BAT sample and aligned to the mouse genome (ENSEMBL 84 release, GRCm38.p4) [12]. The sequence data are available at a publicly accessible database, Gene Expression Omnibus (GEO; https://www.ncbi.nlm.nih.gov/geo/info/seq.html). The accession numbers are GSE112740 for BAT samples and GSE112999 for WAT samples. The differentially expressed genes between lean and obese mice were analyzed using DESeq2 package in R statistical language. Threshold for differential expressed genes is absolute value log2 fold change $>1.5$ and Padj $<0.05$ is considered statistically significant. Low: at least one type of WAT has significantly lower expression than BAT. High: at least one type of WAT has significantly higher expression than BAT. NS: not significantly different expression between BAT and any type of WAT. ND: Not detected. +: upregulated in obese mice. -: downregulated in obese mice. 


\section{Different Types of Adipose Tissues}

\subsection{Location of Adipose Tssues}

It is currently accepted that there are three types of adipose tissues; WAT, BAT, and BeAT. WAT is located in both subcutaneous and visceral regions (Figure 2). Some commonly studied WATs in rodent models are subcutaneous inguinal WAT (IWAT), visceral retroperitoneal WAT (RWAT) positioned behind the kidneys [13], mesenteric and omental WAT (MWAT) located in intestinal region around digestive organs, and gonadal WAT (GWAT; male epididymal WAT or female parametrial and periovarian WAT) which expands during the early stages of obesity [14] and serve as a vital adipose depot for triglyceride storage [15]. WAT location is significant as increased visceral adipose mass is a risk factor related to metabolic disorders such as insulin resistance, while subcutaneous adipose tissue can be protective and improve insulin sensitivity [16-18]. BAT has been detected in the inter-scapular, subscapular, cervical, mediastinal, perirenal, pericardial, and periaortic regions in rodents [19] and humans [20-24]. In rodents, the commonly studied BAT is the interscapular BAT.
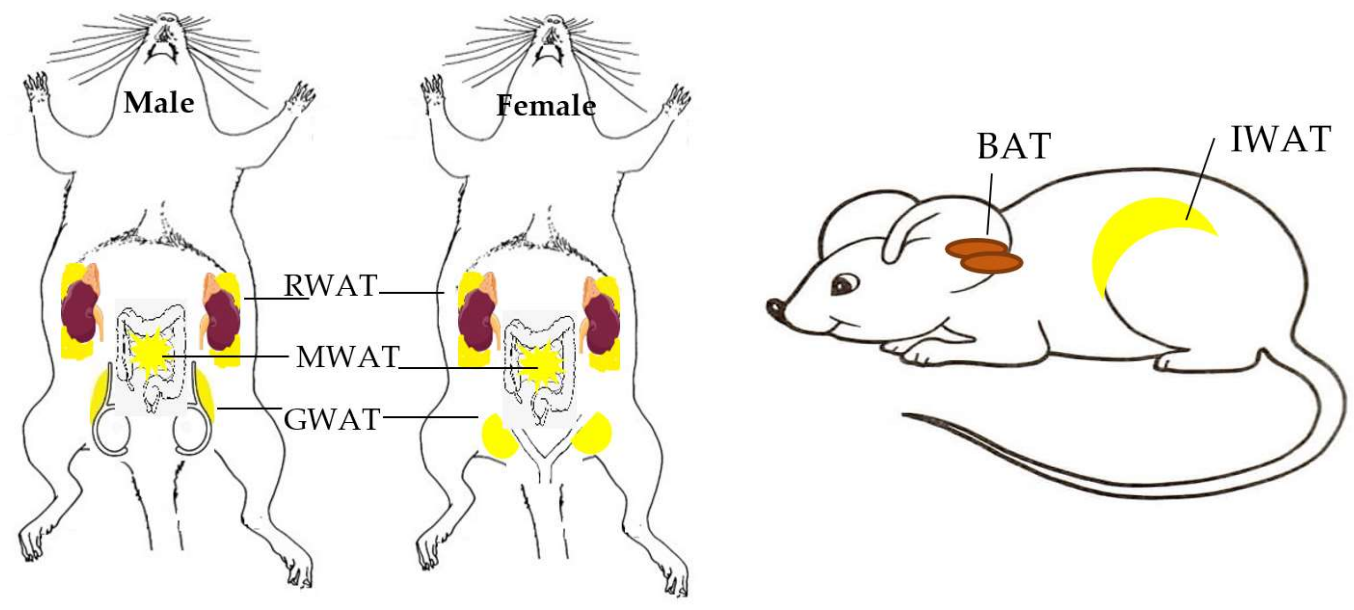

Figure 2. Schematic overview of location of different types of white and brown adipose tissues. Schematic diagrams indicating locations of different types of commonly studied WAT and BAT commonly studied in male and female rodent models, including visceral RWAT, MWAT, and GWAT, as well as subcutaneous IWAT and interscapular BAT.

\subsection{Cellular Properties of Adipose Tssues}

WAT and BAT have very distinct histological and cellular properties. Conventional white adipocytes typically contain single large unilocular lipid droplets and few mitochondria. Conventional brown adipocytes typically consist of numerous multilocular lipid droplets and large amounts of mitochondria. Mitochondria contain high concentrations of iron pigmented-cytochromes, which gives a brownish color to BAT. Mitochondria of BAT feature uncoupling protein 1 (UCP1) in the inner membrane, a protein that uncouples mitochondrial respiration from ATP synthesis leading to energy released as heat [4,25], especially in the setting of a cold environment [3]. Thus, UCP1 is a unique biomarker for thermogenic BAT and BeAT.

Due to heterogeneity and plasticity of adipocytes, white and brown adipocytes change their morphology and function when energy demands are changed under certain physiological or pharmacological conditions. Specifically, in the setting of increased energy demand as seen in cold exposure, brown-like adipocytes develop and emerge in WAT, a process known as "browning"; whereas in a setting of decreased energy demands as seen in high-fat diet feeding, brown adipocytes can be converted to white-like adipocytes, a process termed as "whitening" [26-28]. The development of BeAT in WAT is considered favorable in systemic metabolic regulation [29,30]. A pioneering study reporting beige adipocytes in traditionally WAT first appeared in the literature 25 years ago [31]. 
Specifically, Young et al. reported enlarged BAT at classical BAT depots and presence of adipocytes with similar morphology and UCP1 content as brown adipocytes at parametrial WAT in cold-acclimated mice [31]. Loncar et al. then demonstrated increased mitochondria volume, crista density, and UCP1 expression in IWAT of cold-exposed cats [32] and mice [33], and such changes were reversible following exposure to a warm environment [33]. Cousin et al. further measured UCP1 mRNA and protein levels in several WAT depots in rats, and found that periovarian adipocytes displayed characteristics of brown adipocytes besides UCP1 content, such as increased density of mitochondrial crista [34]. A few research groups "rediscovered" thermogenic beige adipocytes in the recent decade [30,35-37]. Besides cold exposure, increased adrenergic signaling from treatment of adrenergic agonists also induces browning. Chronic administration of a selective $\beta 3$-adrenergic receptor ( $\beta 3$-AR) agonist CL-316 243 triggers multilocular cells emerging in different WAT depots, including GWAT, RWAT, and IWAT, that normally contain only unilocular white adipocytes [38].

Beige, including brown-like and white-like, adipocytes exhibit histological and functional properties that are intermediary between white and brown adipocytes, containing numerous small lipid vacuoles with multilocular lipid droplets, surrounded by well-developed mitochondria [39-45]. One major difference is that, white-like beige adipocytes in BAT developed from whitening process, but not brown-like beige adipocytes in WAT developed from browning process, exhibit signs of inflammation such as increased crown-like structure formation and degenerating mitochondria [28]. As such, BeAT typically indicates the WAT that shelters brown-like beige adipocytes via browning process. Although there is a consensus that the presence of UCP1 expression in WAT is sufficient to define beige adipocytes and development of BeAT, it is unclear what other signatures can differentiate BeAT from typical BAT and how many beige cells must be present in a WAT depot to make it a BeAT.

Differential gene expression analysis of RNA sequencing data indicates that BAT expresses significantly greater level of Ucp 1 than GWAT (Padj < 0.05), but not RWAT or IWAT (Padj > 0.05), in lean and obese mice. Furthermore, four-week high-fat diet feeding does not significantly change Ucp 1 expression in BAT or WAT (Padj > 0.05; Table 1). These data confirm abundant expression of Ucp1 in BAT and differing levels in WAT based on location. GWAT, which predominantly houses white adipocytes has the lowest level of Ucp 1 expression; while RWAT and IWAT, which are known to induce browning under certain conditions [46,47] contain mixed white and thermogenic adipocytes and thus have greater levels of Ucp1 expression than GWAT (Padj < 0.05).

\subsection{Precursors of Adipocytes}

All types of adipocytes originate from multipotent mesenchymal stem cells. Various transcription factors induce differentiation of these stem cells into various types of precursor cells [48-52], ultimately driving cells to develop into adipocytes, myocytes, osteoblasts, chondrocytes, etc. Brown, but not white, adipocytes are derived from myogenic factor expressing progenitor cells of the central dermomyotome [48-50], and brown adipocytes share similar gene expression with myocytes. We have reported that BAT expresses genes involved in muscle development, structure, and contraction process such as those mesodermal developmental genes encoding myogenic factor 6 (Myf6), tropomyosin $\beta$ (Tpm2), and sarcoglycan $\gamma(\mathrm{Sgcg})$, and these genes are downregulated by high-fat diet feeding [12].

When expression levels of these genes are compared between WAT and BAT, BAT in lean mice expresses significantly higher levels of Myf6, Tpm2, and Sgcg than GWAT, RWAT, and IWAT (Padj < 0.05). In obese mice, the differences in expression of these genes by adipose tissue type are much less evident, with only Tpm2 expression remaining significantly higher in BAT than GWAT and IWAT (Padj < 0.05), whereas expression of Tpm 2 between BAT and RWAT and expression of Myf6 and Sgcg between BAT and WAT are similar (Padj $>0.05$ ). The change of differential expression pattern comparing BAT versus WAT between lean and obese mice is due to high-fat diet significantly suppressing expression of Myf6, Tpm2, and Sgcg in BAT (Padj < 0.05) without changing expression of these genes in WAT (Table 1).

These findings confirm that brown adipocytes and myocytes share some common precursors [49] contributing to enriched expression of genes related to muscle differentiation and muscle function in 
BAT [53]. Additionally, depending on their locations, different types of adipocytes arise from different precursor cells and may have unique gene signatures. For example, white adipocytes found in visceral WAT versus subcutaneous WAT express different genes [17]. BAT has been shown to be composed of both brown and beige adipocytes [54]. In humans, brown adipocytes located at BAT depots relatively close to the body surface show gene signature more similar to beige adipocytes $[41,55,56]$, while brown adipocytes found in BAT with deeper locations express classical brown adipocyte-selective markers [57]. Beige adipocytes display some unique molecular signatures that are not shared by either typical brown or white adipocytes. Furthermore, diminished and abolished differences in expression of myocyte-related genes between BAT and WAT by high-fat diet feeding in obese mice are possibly due to whitening process of brown adipocytes. Because white-like and brown-like adipocytes emerge within BAT and WAT, they may differentiate from brown or white adipocyte precursors or transdifferentiate from mature adipocytes.

\subsection{Physiologic Functions of Adipose Tissues}

The major function of WAT is energy storage and release. Energy is accumulated in the form of energy-rich lipid during times of positive energy balance, such as high-fat diet feeding. Stored energy is mobilized to release fatty acids and glycerol via lipolysis during times of negative energy balance, such as during exercise or fasting [3-6]. Thus, WAT plays significant roles in energy homeostasis via storing and releasing energy.

The key roles played by BAT in energy balance regulation has been known for about 40 years [58]. Although amount of active BAT in humans declines with increasing age, the presence of metabolically active BAT in adult humans was demonstrated over 20 years ago in clinical studies using $18 \mathrm{~F}$ fluorodeoxyglucose and positron emission tomography/computed tomography imaging technology for the detection of cancerous tumors $[59,60]$. During the past decade, imaging studies not only have confirmed the presence of functional, metabolically active BAT that contributes to cold-induced thermogenesis in adult healthy humans, but also have revealed that BAT in adults can be activated physiologically or pharmacologically [20-23,61].

BAT and BeAT are thermogenic adipose tissues, which produce heat through energy dissipation for adaptive non-shivering thermogenesis in response to variety of stimuli [21,41-45,56,62-64]. A cold environment increases thermogenic capacity physiologically [21] and upregulates genes involved in lipid metabolism in human BAT, suggesting that BAT activation by cold temperature enhances lipid metabolism in BAT [65]. Studies using genetic mouse models have consistently shown that increased amount and activity of BAT and BeAT would protect from body fat gain, and prevent or correct metabolic dysregulation induced by feeding a high-fat diet [66,67]. In contrast, dysfunction and reduced activity of BAT and BeAT decrease lipid metabolism and lead to obesity [21]. Thus, BAT and BeAT play essential roles in maintaining body temperature and regulating energy metabolism in small mammals, hibernating mammals, and humans $[3,4,20,21,23]$. BAT and BeAT are recognized as potential targets for increasing energy expenditure in the treatment or prevention of obesity, leading to increased research attention on BAT and BeAT due to its therapeutic potential in humans.

\subsection{Secretory Factors of Adipose Tissues}

WAT is not only a site for energy accumulation, but it also functions as an endocrine organ $[4,5]$. Since the seminal discovery of leptin [68], a number of adipose hormones secreted from WAT, known as adipokines, have been identified, and secretory functions of WAT has been confirmed $[69,70]$. When comparing expression of two well-defined WAT adipokines, leptin (Lep) [71] and adiponectin (Adipoq) [72], in WAT and BAT, differential gene expression analysis reveals similar patterns for Lep and Adipoq. First, expression of Lep or Adipoq is not significantly different between WAT and BAT in lean mice (Padj > 0.05). In contrast, each type of WAT expresses significantly greater levels of Lep and Adipoq than BAT of obese mice (Padj < 0.05). Second, high-fat diet-induced changes in expression pattern between WAT and BAT is due to enhanced Lep expression in GWAT, RWAT, and IWAT (Padj < 0.05); 
while a combination of slight suppression of Adipoq expression in BAT (Padj > 0.05) and no change at WAT (Table 1), consistent with increased leptin but reduced adiponectin circulating in obese mice [73]. These RNA sequencing data confirm that expression of these two well-defined WAT adipokines Lep and Adipoq changes with increases in adiposity [73] and are more abundant in WAT than BAT, especially in obese mice.

BAT releases batokines that are distinct from WAT adipokines and functions to facilitate metabolic processes that favor thermogenesis and induction of browning [74]. Some of identified batokines include fibroblast growth factor 21 (FGF21) [75] and neuregulin 4 (NRG4) [76]. These batokines is usually not elevated under basal condition, but are induced during brown adipogenesis, thermogenesis, or browning process. Interleukin 6 (IL-6) is a recently defined batokine from a BAT transplantation study. A few studies have shown improved glucose and lipid metabolism in mice with BAT transplantation [77-80] via enhancing sympathetic activity [77], a phenomenon that requires IL-6 release from transplanted BAT graft [80].

Although IL-6 has been proposed as a batokine [80], hard evidence is lacking. We compare the expression of IL-6 gene (Il6), along with genes encoding two well-identified batokines FGF21 (Fgf21) and NRG4 (Nrg4), between WAT and BAT. Expressions of batokine genes are usually upregulated during thermogenesis or browning, but not at basal conditions without cold exposure or stimulation of adrenal signaling. Like $F g f 21$ and Nrg4, expression of $I l 6$ in BAT is similar between lean and obese mice. It is noteworthy that expression of Nrg4 in GWAT, RWAT, and IWAT is significantly downregulated in high-fat diet-induced obesity (Padj < 0.05), consistent with a recent study [81]. Also similar to Fgf21 and Nrg4, expression of $I l 6$ is abundant in BAT, but is not significantly different from WAT, in lean mice (Padj > 0.05). Different from Fgf21 and Nrg4, expression of $I l 6$ is significantly higher in BAT than RWAT and IWAT in obese mice (Padj < 0.05 ; Table 1). These RNA sequencing data support the idea that IL-6 is a batokine dominantly expressed in BAT.

\section{Innervation of Adipose Tissues}

\subsection{Innervation of Adipose Tissues Regulates Metabolism}

The autonomic nervous system innervating metabolic tissues and organs consists of two major branches, the sympathetic and parasympathetic nervous system (SNS and PSNS, respectively), both of which are primary efferent pathways that involuntarily respond to endogenous and exogenous stimuli [82]. The SNS and its major neurotransmitter norepinephrine upregulate energy mobilization and usage, whereas PSNS and its major neurotransmitter acetylcholine upregulate energy accumulation and storage. Obesity is associated with reduced sympathetic activity or lowered sympathetic response [83]. Sympathetic activity in WAT and BAT in response to different stimuli, such as administration of glucose or insulin [84], cold [21], and physical exercise [85] becomes blunted in obese individuals, which further promotes weight gain [86]. Characterization of neural circuits from the brain to adipose tissues has represented a challenging issue. Below we provide more details regarding the innervation of adipose tissues.

\subsection{Innervation of Adipose Tissues from a Historic View}

BAT innervation was reported many years before the innervation of WAT, with the first report of innervation of BAT at pericardial region appearing in late 1890s [87]. BAT innervation in rodents was then demonstrated by multiple research groups between 1930s and 1960s with differing opinions on the function of innervation, due to the fact that nerve fibers of BAT were seen both at the parenchymal space assumedly innervating brown adipocytes [88] and at vasculature assumedly innervating blood vessels [89]. BAT innervation was further studied using electron microscopy, and both myelinated and unmyelinated nerve fibers were seen at the parenchymal space and around vessels of BAT [90]. Importantly, axon terminals of some unmyelinated nerves containing synaptic vesicles were embedded 
on the surface of adipocytes [90]. This evidence showed brown adipocytes in direct contact with parenchymal nerves, and thus direct innervation of brown adipocytes has been well accepted ever since.

The innervation of WAT has been relatively understudied due to high lipid content in WAT that makes innervation difficult to visualize. It is also challenging to distinguish if terminals synapse on white adipocytes or stromal vascular fractions including vascular endothelial cells of vasculature, fibroblasts, immune cells such as macrophages. Similar to BAT innervation, debate for WAT innervation has focused on the nerve fibers around vasculature. Earlier studies suggested that WAT nerve fibers mostly were perivascular, and white adipocytes were not directly innervated or receive sparse neural inputs [91,92]. It remained uncertain if WAT innervation regulates vascular function or lipid metabolism until the 1990s. Since then much progress has been made in the understanding of different types of innervation of adipose tissues along with its importance in the regulation of energy metabolism.

\subsection{Sympathetic Innervation}

The synaptic vesicles at nerve axon terminals were presumed to contain catecholamines and be of sympathetic origin in early studies [90]. Influential studies by Bartness and colleagues have provided abundant anatomical, histological, biochemical, and functional evidence that have advanced the field of adipose tissue innervation [93]. In early 1990s, Youngstrom and Bartness injected a retrograde fluorescent tract tracer FluoroGold into IWAT and GWAT, and FluoroGold-labeled cells were observed in sympathetic ganglia T13 and T13-L2, respectively. They also injected an anterograde fluorescent tract tracer indocarbocyanine perchlorate into sympathetic ganglion T13, and many labeled cells were seen in the extracellular space surrounding adipocytes in IWAT and GWAT [92]. This pivotal study provided undisputable proof of sympathetic innervation of white adipocytes and not just their vasculature [92].

Bartness and colleagues then demonstrated brain sympathetic neuronal connectivity with WAT and BAT [94,95] using a retrograde tracer, pseudorabies virus (PRV), which only traces sympathetic neurons that are synaptically connected [96]. This method defines hierarchical connectome mapping neuronal pathways from the brain to adipose tissues. They further demonstrated that many PRV-labeled neurons in important regions of the hypothalamus and brainstem involved in regulation of feeding and energy expenditure express tyrosine hydroxylase $(\mathrm{TH})$, a rate-limiting enzyme, and dopamine $\beta$-hydroxylase, the final enzyme, for biosynthesis of norepinephrine. This not only indicated that the labeled circuit marks the sympathetic innervation, but also supported a role for sympathetic innervation of adipose tissues in energy metabolism [97]. Recent studies have demonstrated that different locations of WAT and BAT are governed by diverse neurons and receive different degrees of sympathetic innervation from the brain regions involved in metabolic regulations, with more sympathetic neurons innervating BAT than IWAT throughout the entire neuroaxis [98].

Besides the tracing studies, sympathetic innervation of adipose tissues has been demonstrated using immunohistochemical labeling for sympathetic nerves marker TH using thin adipose sections of $<10 \mu \mathrm{M}$ thickness [77,91,99-101]. Immunohistochemical staining for TH in subcutaneous WAT, visceral WAT, and BAT has shown that TH immunoreactivity at parenchymal nerve fibers increases following cold exposure, which is accompanied by increased UCP1 expression and sympathetic activity $[46,77,101-104]$. Warm temperature elicits the opposite effect in BAT, with decreased sympathetic nerve activity and TH immunoreactivity [105].

\subsection{Sensory Innervation}

Anterograde tracers have been used to trace sensory nerve projections from adipose tissues to dorsal root ganglia that house cell bodies of sensory neurons. Following implantation of True Blue, an anterograde neural tracer, into subcutaneous IWAT, it appears in T13-L3 dorsal root ganglia, indicating sensory innervation of IWAT [106]. H129 strain of herpes simplex virus, an anterograde transneuronal tract tracer, has also been used to trace sensory nerve projections from IWAT and GWAT through T13-L1 dorsal root ganglia [107] and from interscapular BAT through C1-T4 dorsal root ganglia [108] in Siberian hamsters. Besides the tracing studies, sensory innervation of adipose tissue has been 
confirmed by histologically marking sensory nerves with sensory-associated neuropeptides, such as calcitonin gene-related peptide (CGRP) and substance P [91,99,100,109].

WAT sensory innervation is understudied compared to its sympathetic innervation, and its function is not completely understood. It has been proposed that sensory innervation may convey information about adiposity to the brain as an afferent pathway and communicate between the brain and adipose tissues as a feedback mechanism to regulate efferent sympathetic output $[107,108,110]$. Additionally, it is unclear what stimulates the secretion of CGRP or substance P in WAT or BAT and how these sensory nerve-associated neuropeptides affect energy balance. Nevertheless, the presence of both sympathetic and sensory nerves in adipose tissues supports a two-way communication with the brain, through afferent sensory and efferent sympathetic fibers (Figure 1).

\subsection{Parasympathetic Innervation}

All BAT depots receive sympathetic innervation, but only mediastinal and pericardial BAT has parasympathetic innervation [26,111]. Currently it is generally accepted that WAT has negligible or no parasympathetic innervation, but there was a debate around this topic in early 2000s.

Kreier et al. used PRV to mark parasympathetic nerves in rats and suggested the presence of parasympathetic nerves in WAT [112], which was questioned by Giordano et al. when WAT histology failed to label parasympathetic postganglionic nerve markers such as vesicular acetylcholine transporter (VAChT), vasoactive intestinal protein, and neuronal nitric oxide synthase in Siberian hamsters [113]. The marked CNS parasympathetic neurons and vagal innervation could be false positives due to leaking of viral tracer PRV or improper surgical procedure [114]. Kreier et al. responded that lack of parasympathetic nerve marker staining was inadequate to rule out parasympathetic innervation, as these markers were not stable [115]. Berthoud et al. [116] and Giordano et al. [117] further questioned the presence of parasympathetic innervation due to absence of any parasympathetic innervation-related markers for ganglia, nerve, neurotransmitters, etc. at various types of WAT from multiple species tested including mice, rats, and Siberian hamsters.

Recent advances in whole-tissue three-dimensional imaging of adipose nerve fibers using multiphoton microscopy clearly demonstrate that axons project to white adipocytes and form neuro-adipose synaptic connections in the parenchyma of adipose tissues [2,118-120], which helps to clear up confusion and increases our understanding of nerve-adipocyte and nerve-vasculature interactions. A seminal study labels three markers, an adipocyte marker perilipin, a neural pre-synaptic marker synaptophysin, and a sympathetic (TH) or a parasympathetic (VAChT) nerve marker in IWAT, and visualizes and quantifies different types of nerves using this whole-tissue three-dimensional imaging method [121]. This study shows that sympathetic nerve fibers (labeled with $\mathrm{TH}$ ) are located in close contact with approximately $91.3 \%$ of all adipocytes (labeled with perilipin), and $98.8 \%$ of the neural fibers (labeled with synaptophysin) are labeled with $\mathrm{TH}$, suggesting over $90 \%$ of adipocytes are being directly innervated and nearly $99 \%$ of that innervation being sympathetic in IWAT. Additionally, this study helps to clarify the issue of the presence of parasympathetic innervation in WAT, an unsettled controversial issue over the previous decade. Less than five nerve fibers labeled with parasympathetic nerve marker VAChT are detected in each IWAT sample, in contrast to the extensive arborization of fibers labeled with TH [121], supporting the idea of pervasive sympathetic innervation with little to no parasympathetic fibers in WAT [113].

Furthermore, because of the arborization pattern of sympathetic innervation, imaging of whole-tissue, but not thin-sections, is necessary for accurate quantification of innervation. It is worth noting that histology using adipose thin sections is suitable to visualize gross morphology and cellularity such as cell size and cell number related to adiposity change such as hypertrophy versus hyperplasia, cell structure change such as multilocularity versus unilocularity during browning or whitening, expression of UCP1 and nerve markers, and presence of macrophages in crown-like structures; but not suitable to quantify innervation, as cross-sections of nerves appear mostly as puncta, or visualization of synapses. Therefore, TH immunoreactivity in adipose tissues confirms the presence 
of sympathetic innervation, but does not assess quantity or activity of innervation, as expression of $\mathrm{TH}$ fluctuates in response to stimuli that change SNS activity.

\subsection{Expression of Genes Related to Nerve Markers}

RNA sequencing data from different types of adipose tissues of lean and obese mice allows for the analysis of genes encoding $\mathrm{TH}(\mathrm{Th})$, a sympathetic nerve marker; CGRP (Calca), a sensory nerve marker; and VAChT, a.k.a. solute carrier family 18 member 3 (Slc18a3), a parasympathetic nerve marker.

Differential gene expression analysis indicates that, expression of Th is generally abundant in BAT but not significantly different from WAT (Padj > 0.05). Expression of Th in BAT and GWAT is not significantly changed by high-fat diet feeding, but it is no longer detectable at RWAT and IWAT of obese mice, suggesting dramatic reduction in Th expression and thus sympathetic innervation in RWAT and IWAT during high-fat diet-induced obesity development. Expression of Calca is fairly abundant in WAT but not significantly different from BAT (Padj > 0.05). High-fat diet feeding does not significantly change Calca expression in any of WAT or BAT (Padj > 0.05). Interestingly, GWAT, RWAT, and IWAT have a tendency to express greater levels of Calca than BAT in obese mice (log2fold change $>1.5 ;$ Padj $>0.05$ ), indicating that sensory innervation is relatively enhanced at WAT during obesity development, possibly to convey changes in lipid storage to the brain [110]. Bartness and colleagues have begun to understand the functional roles of adipose sensory innervation. They have reported that increased secretion of WAT adipokine leptin [122] and local WAT lipolysis [123] activate WAT sensory innervation, providing mechanisms for selective, depot-specific activation of WAT sensory innervation. These studies, supported by the RNA sequencing findings, indicate reduced sympathetic signal favors WAT lipid accumulation, with increased WAT sensory signal informing the brain of adiposity during obesity development, thus forming a two-way brain-adipose control of energy balance (Figure 1).

Expression of $S l c 18 a 3$ gene for solute carrier family 18 member 3 that transports acetylcholine is not detected in any of interscapular BAT, GWAT, RWAT, or IWAT (Table 1). It is noteworthy that both Slc18a1 gene for solute carrier family 18 member 1 that transports serotonin and Slc18a2 gene for solute carrier family 18 member 2 that transports norepinephrine, dopamine, serotonin, and histamine are expressed in all sequenced adipose tissue samples. The RNA sequencing data are consistent with a previous study showing that only mediastinal and pericardial BAT, but not interscapular BAT sampled in our study, have parasympathetic innervation [26]. The RNA sequencing data are also in accordance with imaging and histologic findings suggesting that parasympathetic innervation of WAT is negligible compared with sympathetic and sensory innervation [121].

\section{Physiological Function of Adipose Tissues Sympathetic Innervation}

\subsection{Function of Sympathetic Innervation of WAT}

Various stimuli that change energy fluxes modulate the SNS, which further regulates lipolysis, lipogenesis, adipocyte proliferation, and adipokine secretion $[69,70,124]$. Upon sympathetic stimulation, increases in firing rates of the sympathetic neurons that innervate adipose tissues induce secretion of norepinephrine at sympathetic postganglionic nerve terminals of surrounding adipocytes, subsequently activating $\beta 3-\mathrm{AR}$, a $\mathrm{G}$ protein-coupled receptor [125] and adenylate cyclase, which increases intracellular levels of cyclic adenosine monophosphate (cAMP). cAMP functions as a second messenger and activates protein kinase A (PKA) [126].

In white adipocytes, PKA phosphorylates perilipin, a lipid droplet-associated protein, and a series of lipases and esterases that convert stored triglycerides to diacylglycerol and monoacylglycerol [126], and via a cascade of steps of lipolysis eventually to fatty acids and glycerol that can be used as energy fuels of other tissues [2] (Figure 3). Function of sympathetic innervation in lipolysis at WAT has been directly assessed using optogenetic nerve stimulation. An optical fiber is implanted unilaterally into subcutaneous IWAT, and nerve stimulation leads to norepinephrine release, phosphorylation 
of hormone-sensitive lipase (HSL), and increased fatty acid release upon stimulation, compared to contralateral un-stimulated IWAT [2]. This study provides direct functional evidence that activation of sympathetic fibers is adequate to facilitate norepinephrine release and lipolysis [2]. Furthermore, visceral WAT depots mobilize their lipid to a greater extent than subcutaneous WAT depots following sympathetic action. For example, lipolysis at RWAT shows great response to pharmacological stimulation by $\beta 3-A R$ agonists [127]. WAT sympathetic activation also inhibits adipocyte proliferation and WAT expansion, with greater inhibition of expansion in subcutaneous IWAT compared to visceral RWAT [128].
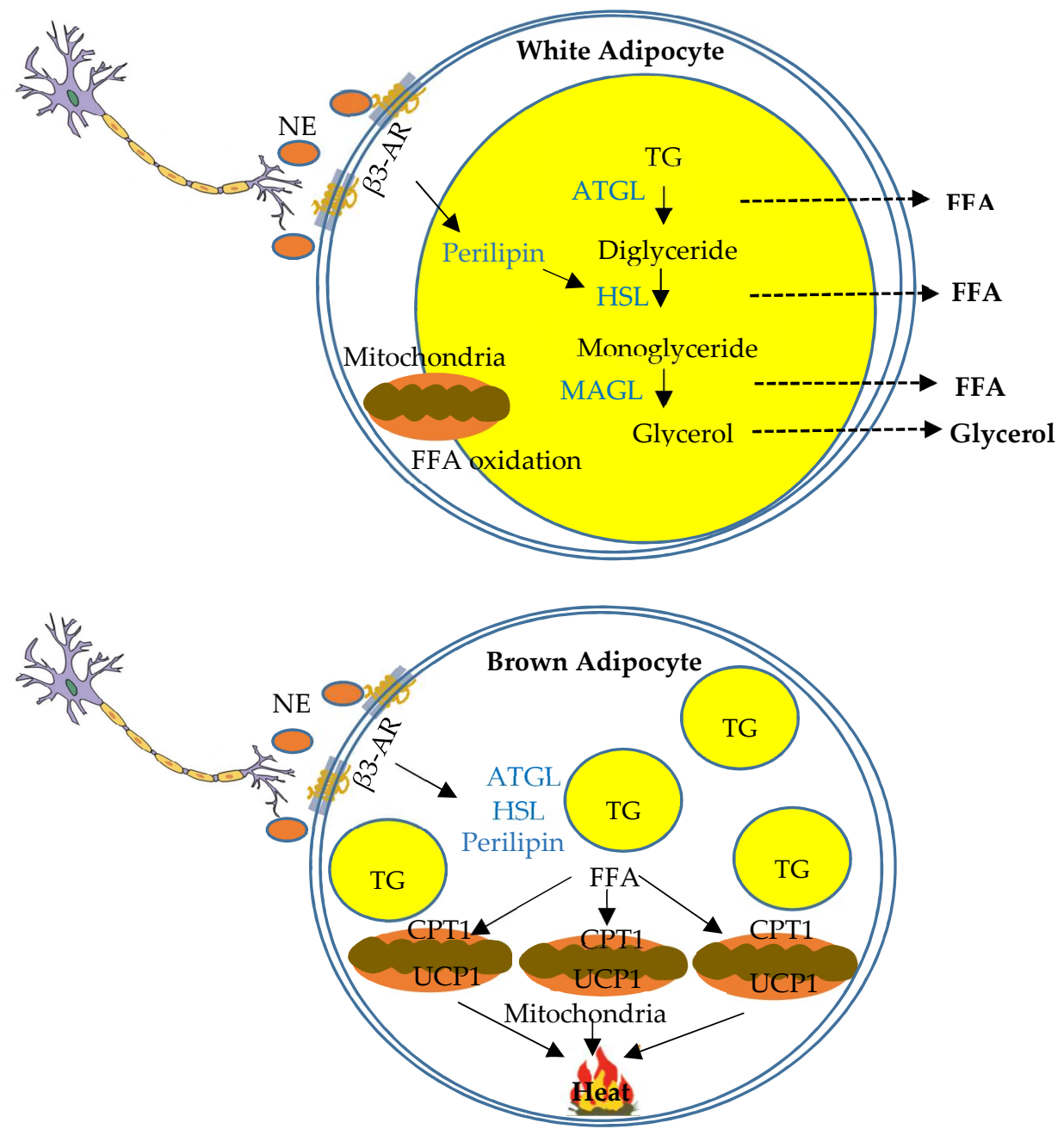

Figure 3. Schematic overview of function of sympathetic innervation of white and brown adipose tissues in the regulation of lipid metabolism. Schematic diagram indicating lipolysis and thermogenesis in white and brown adipocytes respectively regulated by sympathetic innervation. In white adipocytes, sympathetic innervation regulates a cascade of lipolysis to convert stored triglycerides (TG) to free fatty acids (FFA) and glycerol that can be used as fuels of other tissues. In brown adipocytes, sympathetic innervation regulates non-shivering thermogenesis. FFAs are transferred into mitochondria, primarily by carnitine palmitoyltransferase 1 (CPT1), and serve as fuel for $\beta$-oxidation. UCP1 is activated to disassociate respiratory chain from ATP production, and ultimately dissipates energy as heat.

\subsection{Function of Sympathetic Innervation of BAT}

As mentioned previously, it has been known for over a century that there is sympathetic innervation of BAT [87]. Since then, studies have supported the idea that catecholamines drive BAT non-shivering thermogenesis that plays an integral role in body temperature maintenance in various mammalian 
species including humans [108,129-134]. Sympathetic activation of BAT thermogenesis promotes heat dissipation of the energy contained in triglycerides. In brown adipocytes, free fatty acids are transferred into mitochondria following sympathetic stimulation by carnitine palmitoyltransferase 1 (CPT1) located at the outer membrane of mitochondria. Inside the mitochondria, free fatty acids serve as fuel for $\beta$-oxidation, which produces NADH and FADH that are later oxidized in the electron transport chain. NE and $\beta 3$-AR interaction and subsequent PKA-dependent processes lead to increased expression of UCP1, which disassociates the activity of the respiratory chain from ATP production, mediates proton reentry into mitochondrial membrane, converts energy of proton gradient into heat, and ultimately dissipates energy as heat $[3,4,132,135]$ (Figure 3).

The role of sympathetic activity in browning of white adipocytes and the development of BeAT has been more recently described [30]. Various transcriptional regulators drive distinct steps of this process, leading to the differentiation of preadipocytes into brown or beige adipocytes, increased mitochondrial biogenesis, and overexpression of thermogenic proteins such as UCP1 [136]. For example, members of peroxisome proliferator-activated receptor (PPAR) family, CCAAT/enhancer-binding protein (C/EBP) family, and bone morphogenic protein family [48] are important transcriptional factors specific to adipocyte differentiation $[56,137]$. Specifically, activation of C/EBP $\beta$, which cooperates with a dominant transcriptional co-regulator PR domain containing 16 (PRDM16) [138], induces PPAR $\gamma$ and C/EBP $\alpha$ expressed in preadipocytes, acts jointly to promote adipocyte differentiation and adipogenesis [137], which determines brown adipocyte lineage or enhances white adipocyte browning [139]. Members of PPAR family and C/EBP family have been implicated as key enhancers for browning of adipocytes and adipogenesis [27,140-142]. In addition, the hypothalamic AMP-activated protein kinase activates WAT sympathetic innervation to promote browning [104]. It is possible that members of PPAR family and C/EBP family at adipose tissues are regulated by sympathetic activity from certain stimuli, which subsequently controls adipocyte differentiation and proliferation as well as browning of white adipocytes. The events underlying browning processes regulated by distinct endogenous factors and environmental stimuli are far from fully established [136].

\subsection{Comparison of Sympathetic Function and Gene Markers between WAT and BAT}

Sympathetic innervation is differentially activated and performs differing functions in WAT and BAT. For example, in response to calorie overload, sympathetic activity in BAT increases to promote energy expenditure, whereas sympathetic activity in WAT decreases to promote lipogenesis and lipid accumulation. In contrast, in response to fasting or high-fat to low-fat diet switch, sympathetic activity in BAT, along with many other tissues, decreases to conserve energy expenditure, whereas sympathetic activity in WAT increases to promote lipid mobilization and fatty acid release for other tissues to use $[103,143,144]$. In response to a cold environment, sympathetic activity in both BAT and WAT increases to provide substrates for non-shivering thermogenesis to maintain body temperature $[145,146]$. Therefore, sympathetic regulation of lipid metabolism varies in WAT and BAT through discrete sympathetic projections [147], which diverge to coordinate WAT lipolysis and BAT thermogenesis, leading to finely tuned control of whole-body energy homeostasis [148].

Intracellularly, early steps upon sympathetic stimulation involving activation of $\beta 3-A R$ and adenylate cyclase, cAMP production, and PKA activation are common in both white and brown adipocytes. PKA then phosphorylates and activates specific intracellular target proteins in different type of cells. Lipolysis and fatty acid release involving activation of HSL is dominant in white adipocytes, and fatty acid oxidation involving CPT1 is dominant in brown adipocytes. Data from the comparison of the expression of HSL gene (Lipe) and CPT1 gene (Cpt1b) in WAT and BAT support lipolytic function of WAT and fatty acid oxidation of BAT as major mechanisms to reduce lipid accumulation and regulate whole-body lipid metabolism.

Differential gene expression analysis indicates that, high-fat diet feeding does not significantly change Lipe expression in WAT or BAT (Padj > 0.05). Expression of Lipe is similar between WAT and BAT in lean mice (Padj > 0.05), whereas subcutaneous IWAT, but not visceral GWAT or RWAT, 
expresses significantly greater expression of Lipe than BAT in obese mice (Padj $<0.05)$. These RNA sequencing data indicate more abundant Lipe expression in subcutaneous IWAT relative to BAT in high-fat diet fed obese mice, suggesting selective lipid mobilization at subcutaneous WAT but not at visceral WAT during calorie overload. This finding corroborates that lipid accumulation mostly occurs at visceral WAT during obesity development.

Differential gene expression analysis indicates that BAT expresses significantly greater $C p t 1 b$ than GWAT and RWAT in both lean and obese mice (Padj < 0.05), while BAT has a trend to express greater level of $C p t 1 b$ than IWAT (log2fold change $>1.5$; Padj $>0.05$ ). Additionally, there is a trend of upregulation of Cpt1b expression in BAT in obese mice (log2fold change $>1.5$; Padj $>0.05$ ) (Table 1$)$. These data indicate more abundant $C p t 1 b$ expression in BAT than WAT, and support increased fatty acid oxidation at BAT leading to enhanced energy expenditure, contributing to the homeostatic regulation of whole-body adiposity during obesity development.

\subsection{Studying Sympathetic Function of Adipose Tissues via Denervation}

Denervation of WAT of BAT is a great tool for studying sympathetic functions, a topic that was comprehensively reviewed recently [149]. Denervation studies demonstrate metabolic perturbations following loss of the nerve supply to WAT or BAT. Surgical denervation of WAT increases adipose mass, reduces lipolysis, and promotes white adipocyte proliferation and differentiation in rats [150] and Siberian hamsters $[92,99,100,128]$. Surgical denervation of BAT decreases expression of TH [151] and UCP1 [152], and leads to impaired thermogenesis, reduced energy expenditure, increased body fat mass [153], and "whitening" of BAT [151]. These studies highlight the importance of WAT innervation in regulating lipolysis and proliferation, and BAT innervation in regulating thermogenesis and browning. Therefore, denervation studies add credence and further support neural control of metabolism by innervation of WAT and BAT.

Surgical denervation is considered more effective at eliminating neural input and output, as the nerve bundles are physically severed, while vasculature is left intact. Surgical denervation, however, is not specific to nerve type, as sympathetic and sensory nerves bundle and travel together, thus both are severed. Although surgical denervation can be used to differentiate neural and endocrine effects on metabolic regulation, it is not able to reveal which nerve type is relatively more essential in maintaining certain metabolic effects.

An alternative approach is chemical denervation that removes a selective type of nerve supply to WAT and BAT. Chemical sympathetic denervation typically uses 6-hydroxydopamine [154], which is taken up into norepinephrine storage vesicles, leading to oxidative damage to vesicle membrane and nerve degeneration, thereby producing denervation of sympathetic nerves while leaving sensory nerves intact [149]. Chemical sympathetic denervation reduces expression of TH and norepinephrine content without changing CGRP level, indicating intact sensory innervation, in BAT [98] and WAT [113]. Chemical sensory denervation typically uses 8-methyl- $N$-vanillyl-6-noneamide (i.e., capsaicin), the pungent principle of hot chili peppers, which over-activates vanilloid receptor (i.e., capsaicin receptor) and leads to influx of calcium and sodium ions, an excitotoxic effect that destroys small diameter nociceptive sensory neurons along with unmyelinated and myelinated sensory nerves [149]. Chemical sensory denervation reduces contents of CGRP and substance $\mathrm{P}$, and leaves sympathetic nerves intact in BAT [155] and WAT [100,110]. Chemical denervation, however, has certain drawbacks including intra-tissue injuries related to multiple injections, uneven distribution of neurotoxins leading to lack of uniform damage, lower efficacy in eliminating TH- or CGRP-immunoreactivity compared to surgical denervation [100], and possible "reconnection" of damaged fibers as nerve markers reappear after a certain period of time following injection [156].

WAT sympathetic denervation results in increased adipose mass characterized by an increase in cell number and a decrease in lipolysis, which supports a mechanism by which the sympathetic nerves regulate lipid metabolism via regulating adipocyte proliferation and lipolysis [149]. Bilateral BAT sympathetic denervation increases sympathetic activity of IWAT [98], demonstrating adipose 
tissue crosstalk with the brain to maintain energy homeostasis. Similar to BAT chemical sympathetic denervation and in contrast to WAT sympathetic denervation, WAT sensory denervation increases adipose mass via hypertrophy instead of hyperplasia [99,100], providing a means of differential control of WAT by sympathetic versus sensory nerves. BAT sensory denervation also impairs thermogenesis [157], demonstrating the need for sensory feedback from BAT for proper thermogenic function. Therefore, chemical denervation helps to deepen the understanding of action of specific nerve types in adipose tissue, as well as feedback neurocircuit that involves the brain and multiple peripheral tissues and incorporates both afferent sensory and efferent sympathetic nerves.

\section{Conclusions}

Obesity manifested as excessive lipid storage in adipose tissue is due to metabolic dysregulation of energy homeostasis. WAT accumulates excess energy and BAT functions as a thermogenic organ in response to metabolic challenges such as diet and cold, thus both are vital for the regulation of lipid metabolism and body weight. The SNS plays a primary role in the regulation of BAT and BeAT thermogenic activation and fatty acid oxidation, as well as WAT lipolysis, lipogenesis, and browning (Figure 1). The functions of the SNS in these key metabolic processes represent potential therapeutic targets for treating obesity.

New whole-adipose imaging and genomic analysis have advanced understanding of adipose tissue innervation, transcriptome, and secretome. However, there is still much unknown regarding to gene signatures of different types of adipocytes; adipose tissue innervation, especially in terms of the innervation, transcriptome, and secretome of BeAT; how chemical messengers, including locally secreted WAT adipokines and BAT batokines, circulating hormones from other organs, neuropeptides and neurotransmitters from adjacent nerves, and affect sympathetic and sensory innervation of WAT and BAT; and feedback regulation to control lipid metabolism. Additionally, the concept of brain regulating lipid metabolism via innervation of WAT and BAT is well accepted, but most of current knowledge is obtained from animal studies using rodents. It is uncertain if humans have similar afferent and efferent neural circuits and feedback regulation of adipose tissues. More studies are needed to identify neuroanatomic and synaptic structures of, metabolic functions, and chemical messengers released from and used by each type of nerves in WAT and BAT. Now is an exciting time for further research in neuroendocrine regulation of lipid metabolism at different types of adipose tissues.

Funding: This study was supported by Sigma Xi Grants-in-Aid G2017031588446675 (Q.Z.), American Heart Association 16GRNT31110008 (H.S.), Undergraduate Research Award (B.J.G., B.C.H.), Dean's Scholarship (B.C.H.), Howard Hughes Summer Internship (B.J.G.), and Madalene and George Shetler Diabetes Research Award (H.S.) from Miami University.

Conflicts of Interest: The authors declare no conflict of interest. The founding sponsors had no role in the design of the study; in the collection, analyses, or interpretation of data; in the writing of the manuscript, and in the decision to publish the results.

\section{Abbreviations}

$\begin{array}{ll}\text { AR } & \text { adrenergic receptor } \\ \text { BAT } & \text { brown adipose tissue } \\ \text { BeAT } & \text { beige adipose tissue } \\ \text { C/EBP } & \text { CCAAT/enhancer-binding protein } \\ \text { CGRP } & \text { calcitonin gene-related peptide } \\ \text { CTP1 } & \text { carnitine palmitoyltransferase 1 } \\ \text { CNS } & \text { central nervous system } \\ \text { FGF21 } & \text { fibroblast growth factor 21 } \\ \text { GWAT } & \text { gonadal WAT } \\ \text { HSL } & \text { hormone-sensitive lipase } \\ \text { IL-6 } & \text { interleukin 6 }\end{array}$




$\begin{array}{ll}\text { IWAT } & \text { inguinal WAT } \\ \text { LFD } & \text { low-fat diet } \\ \text { PRV } & \text { pseudorabies virus } \\ \text { PSNS } & \text { parasympathetic nervous system } \\ \text { RWAT } & \text { retroperitoneal WAT } \\ \text { SNS } & \text { sympathetic nervous system } \\ \text { TH } & \text { tyrosine hydroxylase } \\ \text { UCP1 } & \text { uncoupling protein 1 } \\ \text { VAChT } & \text { vesicular acetylcholine transporter } \\ \text { WAT } & \text { white adipose tissue }\end{array}$

\section{References}

1. Nguyen, P.; Leray, V.; Diez, M.; Serisier, S.; Bloc'h, J.L.; Siliart, B.; Dumon, H. Liver lipid metabolism. J. Anim. Physiol. Anim. Nutr. 2008, 92, 272-283. [CrossRef] [PubMed]

2. Zeng, W.; Pirzgalska, R.M.; Pereira, M.M.; Kubasova, N.; Barateiro, A.; Seixas, E.; Lu, Y.H.; Kozlova, A.; Voss, H.; Martins, G.G.; et al. Sympathetic neuro-adipose connections mediate leptin-driven lipolysis. Cell 2015, 163, 84-94. [CrossRef]

3. Cannon, B.; Nedergaard, J. Brown adipose tissue: Function and physiological significance. Physiol. Rev. 2004, 84, 277-359. [CrossRef] [PubMed]

4. Contreras, C.; Gonzalez, F.; Fernø, J.; Diéguez, C.; Rahmouni, K.; Nogueiras, R.; López, M. The brain and brown fat. Ann. Med. 2015, 47, 150-168. [CrossRef] [PubMed]

5. Villarroya, F.; Vidal-Puig, A. Beyond the sympathetic tone: The new brown fat activators. Cell Metab. 2013, 17, 638-643. [CrossRef]

6. Bjørndal, B.; Burri, L.; Staalesen, V.; Skorve, J.; Berge, R.K. Different adipose depots: Their role in the development of metabolic syndrome and mitochondrial response to hypolipidemic agents. J. Obes. 2011, 2011. [CrossRef]

7. Hales, C.M.; Carroll, M.D.; Fryar, C.D.; Ogden, C.L. Prevalence of Obesity among Adults and Youth: United States, 2015-2016. Available online: https://www.cdc.gov/nchs/products/databriefs/db288.htm (accessed on 25 April 2019).

8. McAllister, E.J.; Dhurandhar, N.V.; Keith, S.W.; Aronne, L.J.; Barger, J.; Baskin, M.; Benca, R.M.; Biggio, J.; Boggiano, M.M.; Eisenmann, J.C.; et al. Ten putative contributors to the obesity epidemic. Crit. Rev. Food Sci. Nutr. 2009, 49, 868-913. [CrossRef]

9. Reaven, G. Insulin resistance, cardiovascular disease and the metabolic syndrome: How well do the emperor's clothes fit? Diabetes Care 2004, 27, 1011-1012. [CrossRef] [PubMed]

10. Reaven, G.M. Insulin resistance: The link between obesity and cardiovascular disease. Med. Clin. N. Am. 2011, 95, 875-892. [CrossRef] [PubMed]

11. Flegal, K.M.; Panagiotou, O.A.; Graubard, B.I. Estimating population attributable fractions to quantify the health burden of obesity. Ann. Epidemiol. 2015, 25, 201-207. [CrossRef] [PubMed]

12. Cao, J.; Zhu, Q.; Liu, L.; Glazier, B.J.; Hinkel, B.C.; Liang, C.; Shi, H. Global transcriptome analysis of brown adipose tissue of diet-induced obese mice. Int. J. Mol. Sci. 2018, 19, 1095. [CrossRef]

13. Hung, C.-S.; Lee, J.-K.; Yang, C.-Y.; Hsieh, H.-R.; Ma, W.-Y.; Lin, M.-S.; Liu, P.-H.; Shih, S.-R.; Liou, J.-M.; Chuang, L.-M.; et al. Measurement of visceral fat: Should we include retroperitoneal fat? PLoS ONE 2014, 9, e112355. [CrossRef]

14. Van Beek, L.; van Klinken, J.B.; Pronk, A.C.M.; van Dam, A.D.; Dirven, E.; Rensen, P.C.N.; Koning, F.; Willems van Dijk, K.; van Harmelen, V. The limited storage capacity of gonadal adipose tissue directs the development of metabolic disorders in male C57Bl/6J mice. Diabetologia 2015, 58, 1601-1609. [CrossRef] [PubMed]

15. Wang, S.; Matthan, N.R.; Wu, D.; Reed, D.B.; Bapat, P.; Yin, X.; Grammas, P.; Shen, C.-L.; Lichtenstein, A.H. Lipid content in hepatic and gonadal adipose tissue parallel aortic cholesterol accumulation in mice fed diets with different omega-6 PUFA to EPA plus DHA ratios. Clin. Nutr. 2014, 33, 260-266. [CrossRef]

16. Kwon, H.; Kim, D.; Kim, J.S. Body fat distribution and the risk of incident metabolic syndrome: A longitudinal cohort study. Sci. Rep. 2017, 7, 10955. [CrossRef] [PubMed] 
17. Chau, Y.-Y.; Bandiera, R.; Serrels, A.; Martínez-Estrada, O.M.; Qing, W.; Lee, M.; Slight, J.; Thornburn, A.; Berry, R.; McHaffie, S.; et al. Visceral and subcutaneous fat have different origins and evidence supports a mesothelial source. Nat. Cell Biol. 2014, 16, 367-375. [CrossRef] [PubMed]

18. Kim, J.-Y.; van de Wall, E.; Laplante, M.; Azzara, A.; Trujillo, M.E.; Hofmann, S.M.; Schraw, T.; Durand, J.L.; Li, H.; Li, G.; et al. Obesity-associated improvements in metabolic profile through expansion of adipose tissue. J. Clin. Investig. 2007, 117, 2621-2637. [CrossRef] [PubMed]

19. Cinti, S. The Adipose Organ; Editrice Kurtis: Milan, Italy, 1999.

20. Cypess, A.M.; Lehman, S.; Williams, G.; Tal, I.; Rodman, D.; Goldfine, A.B.; Kuo, F.C.; Palmer, E.L.; Tseng, Y.-H.; Doria, A.; et al. Identification and importance of brown adipose tissue in adult humans. N. Engl. J. Med. 2009, 360, 1509-1517. [CrossRef] [PubMed]

21. Van Marken Lichtenbelt, W.D.; Vanhommerig, J.W.; Smulders, N.M.; Drossaerts, J.M.; Kemerink, G.J.; Bouvy, N.D.; Schrauwen, P.; Teule, G.J.J. Cold-activated brown adipose tissue in healthy men. N. Engl. J. Med. 2009, 360, 1500-1508. [CrossRef]

22. Nedergaard, J.; Bengtsson, T.; Cannon, B. Unexpected evidence for active brown adipose tissue in adult humans. Am. J. Physiol. Endocrinol. Metab. 2007, 293, E444-E452. [CrossRef]

23. Virtanen, K.A.; Lidell, M.E.; Orava, J.; Heglind, M.; Westergren, R.; Niemi, T.; Taittonen, M.; Laine, J.; Savisto, N.-J.; Enerbäck, S.; et al. Functional brown adipose tissue in healthy adults. N. Engl. J. Med. 2009, 360, 1518-1525. [CrossRef]

24. Zingaretti, M.C.; Crosta, F.; Vitali, A.; Guerrieri, M.; Frontini, A.; Cannon, B.; Nedergaard, J.; Cinti, S. The presence of UCP1 demonstrates that metabolically active adipose tissue in the neck of adult humans truly represents brown adipose tissue. FASEB J. 2009, 23, 3113-3120. [CrossRef]

25. Villarroya, J.; Cereijo, R.; Villarroya, F. An endocrine role for brown adipose tissue? Am. J. Physiol. Endocrinol. Metab. 2013, 305, E567-E572. [CrossRef]

26. Giordano, A.; Frontini, A.; Castellucci, M.; Cinti, S. Presence and distribution of cholinergic nerves in rat mediastinal brown adipose tissue. J. Histochem. Cytochem. 2004, 52, 923-930. [CrossRef] [PubMed]

27. Fisher, F.M.; Kleiner, S.; Douris, N.; Fox, E.C.; Mepani, R.J.; Verdeguer, F.; Wu, J.; Kharitonenkov, A.; Flier, J.S.; Maratos-Flier, E.; et al. FGF21 regulates PGC-1 $\alpha$ and browning of white adipose tissues in adaptive thermogenesis. Genes Dev. 2012, 26, 271-281. [CrossRef] [PubMed]

28. Kotzbeck, P.; Giordano, A.; Mondini, E.; Murano, I.; Severi, I.; Venema, W.; Cecchini, M.P.; Kershaw, E.E.; Barbatelli, G.; Haemmerle, G.; et al. Brown adipose tissue whitening leads to brown adipocyte death and adipose tissue inflammation. J. Lipid Res. 2018, 59, 784-794. [CrossRef] [PubMed]

29. Rosen, E.D.; Spiegelman, B.M. What we talk about when we talk about fat. Cell 2014, 156, 20-44. [CrossRef] [PubMed]

30. Harms, M.; Seale, P. Brown and beige fat: Development, function and therapeutic potential. Nat. Med. 2013, 19, 1252-1263. [CrossRef]

31. Young, P.; Arch, J.R.S.; Ashwell, M. Brown adipose tissue in the parametrial fat pad of the mouse. FEBS Lett. 1984, 167, 10-14. [CrossRef]

32. Lončar, D.; Bedrica, L.; Mayer, J.; Cannon, B.; Nedergaard, J.; Afzelius, B.A.; Švajger, A. The effect of intermittent cold treatment on the adipose tissue of the cat: Apparent transformation from white to brown adipose tissue. J. Ultrastruct. Mol. Struct Res. 1986, 97, 119-129. [CrossRef]

33. Lončar, D. Convertible adipose tissue in mice. Cell Tissue Res. 1991, 266, 149-161. [CrossRef]

34. Cousin, B.; Cinti, S.; Morroni, M.; Raimbault, S.; Ricquier, D.; Penicaud, L.; Casteilla, L. Occurrence of brown adipocytes in rat white adipose tissue: Molecular and morphological characterization. J. Cell Sci. 1992, 103, 931-942. [PubMed]

35. Petrovic, N.; Walden, T.B.; Shabalina, I.G.; Timmons, J.A.; Cannon, B.; Nedergaard, J. Chronic peroxisome proliferator-activated receptor gamma (PPAR $\gamma$ ) activation of epididymally derived white adipocyte cultures reveals a population of thermogenically competent, UCP1-containing adipocytes molecularly distinct from classic brown adipocytes. J. Biol. Chem. 2010, 285, 7153-7164. [CrossRef] [PubMed]

36. Ishibashi, J.; Seale, P. Beige can be slimming. Science 2010, 328, 1113-1114. [CrossRef] [PubMed]

37. Vegiopoulos, A.; Müller-Decker, K.; Strzoda, D.; Schmitt, I.; Chichelnitskiy, E.; Ostertag, A.; Diaz, M.B.; Rozman, J.; Hrabe de Angelis, M.; Nüsing, R.M.; et al. Cyclooxygenase-2 controls energy homeostasis in mice by de novo recruitment of brown adipocytes. Science 2010, 328, 1158-1161. [CrossRef] [PubMed] 
38. Himms-Hagen, J.; Cui, J.; Danforth, E.J.; Taatjes, D.J.; Lang, S.S.; Waters, B.L.; Claus, T.H. Effect of CL-316,243, a thermogenic beta 3-agonist, on energy balance and brown and white adipose tissues in rats. Am. J. Physiol. 1994, 266, R1371-R1382. [CrossRef] [PubMed]

39. Lee, Y.-H.; Mottillo, E.P.; Granneman, J.G. Adipose tissue plasticity from WAT to BAT and in between. Biochim. Biophys Acta 2014, 1842, 358-369. [CrossRef]

40. Lim, S.; Honek, J.; Xue, Y.; Seki, T.; Cao, Z.; Andersson, P.; Yang, X.; Hosaka, K.; Cao, Y. Cold-induced activation of brown adipose tissue and adipose angiogenesis in mice. Nat. Protoc. 2012, 7, 606-615. [CrossRef]

41. Jespersen, N.Z.; Larsen, T.J.; Peijs, L.; Daugaard, S.; Homøe, P.; Loft, A.; de Jong, J.; Mathur, N.; Cannon, B.; Nedergaard, J.; et al. A classical brown adipose tissue mRNA signature partly overlaps with brite in the supraclavicular region of adult humans. Cell Metab. 2013, 17, 798-805. [CrossRef]

42. Wu, J.; Boström, P.; Sparks, L.M.; Ye, L.; Choi, J.H.; Giang, A.-H.; Khandekar, M.; Virtanen, K.A.; Nuutila, P.; Schaart, G.; et al. Beige adipocytes are a distinct type of thermogenic fat cell in mouse and human. Cell 2012, 150, 366-376. [CrossRef]

43. Lidell, M.E.; Betz, M.J.; Leinhard, O.D.; Heglind, M.; Elander, L.; Slawik, M.; Mussack, T.; Nilsson, D.; Romu, T.; Nuutila, P.; et al. Evidence for two types of brown adipose tissue in humans. Nat. Med. 2013, 19, 631-634. [CrossRef] [PubMed]

44. Sharp, L.Z.; Shinoda, K.; Ohno, H.; Scheel, D.W.; Tomoda, E.; Ruiz, L.; Hu, H.; Wang, L.; Pavlova, Z.; Gilsanz, V.; et al. Human BAT possesses molecular signatures that resemble beige/brite cells. PLoS ONE 2012, 7, e49452. [CrossRef]

45. Lee, Y.-K.; Cowan, C.A. White to brite adipocyte transition and back again. Nat. Cell Biol. 2013, 15, 568-569. [CrossRef] [PubMed]

46. Guerra, C.; Koza, R.A.; Yamashita, H.; Walsh, K.; Kozak, L.P. Emergence of brown adipocytes in white fat in mice is under genetic control. Effects on body weight and adiposity. J. Clin. Investig. 1998, 102, 412-420. [CrossRef]

47. Rosenwald, M.; Perdikari, A.; Rülicke, T.; Wolfrum, C. Bi-directional interconversion of brite and white adipocytes. Nat. Cell Biol. 2013, 15, 659. [CrossRef]

48. Tseng, Y.-H.; Kokkotou, E.; Schulz, T.J.; Huang, T.L.; Winnay, J.N.; Taniguchi, C.M.; Tran, T.T.; Suzuki, R.; Espinoza, D.O.; Yamamoto, Y.; et al. New role of bone morphogenetic protein 7 in brown adipogenesis and energy expenditure. Nature 2008, 454, 1000-1004. [CrossRef] [PubMed]

49. Timmons, J.A.; Wennmalm, K.; Larsson, O.; Walden, T.B.; Lassmann, T.; Petrovic, N.; Hamilton, D.L.; Gimeno, R.E.; Wahlestedt, C.; Baar, K.; et al. Myogenic gene expression signature establishes that brown and white adipocytes originate from distinct cell lineages. Proc. Natl. Acad. Sci. USA 2007, 104, 4401-4406. [CrossRef] [PubMed]

50. Seale, P.; Bjork, B.; Yang, W.; Kajimura, S.; Chin, S.; Kuang, S.; Scime, A.; Devarakonda, S.; Conroe, H.M.; Erdjument-Bromage, H.; et al. PRDM16 controls a brown fat/skeletal muscle switch. Nature 2008, 454, 961-967. [CrossRef]

51. Shan, T.; Liang, X.; Bi, P.; Zhang, P.; Liu, W.; Kuang, S. Distinct populations of adipogenic and myogenic Myf5-lineage progenitors in white adipose tissues. J. Lipid Res. 2013, 54, 2214-2224. [CrossRef] [PubMed]

52. Sanchez-Gurmaches, J.; Guertin, D.A. Adipocytes arise from multiple lineages that are heterogeneously and dynamically distributed. Nat. Commun. 2014, 5, 4099. [CrossRef]

53. Fitzgibbons, T.P.; Kogan, S.; Aouadi, M.; Hendricks, G.M.; Straubhaar, J.; Czech, M.P. Similarity of mouse perivascular and brown adipose tissues and their resistance to diet-induced inflammation. Am. J. Physiol. Heart Circ. Physiol. 2011, 301, H1425-H1437. [CrossRef] [PubMed]

54. Kim, S.H.; Plutzky, J. Brown fat and browning for the treatment of obesity and related metabolic disorders. Diabetes Metab. J. 2016, 40, 12-21. [CrossRef] [PubMed]

55. Shinoda, K.; Luijten, I.H.N.; Hasegawa, Y.; Hong, H.; Sonne, S.B.; Kim, M.; Xue, R.; Chondronikola, M.; Cypess, A.M.; Tseng, Y.-H.; et al. Genetic and functional characterization of clonally derived adult human brown adipocytes. Nat. Med. 2015, 21, 389-394. [CrossRef]

56. Wu, J.; Cohen, P.; Spiegelman, B.M. Adaptive thermogenesis in adipocytes: Is beige the new brown? Genes Dev. 2013, 27, 234-250. [CrossRef]

57. Cypess, A.M.; White, A.P.; Vernochet, C.; Schulz, T.J.; Xue, R.; Sass, C.A.; Huang, T.L.; Roberts-Toler, C.; Weiner, L.S.; Sze, C.; et al. Anatomical localization, gene expression profiling and functional characterization of adult human neck brown fat. Nat. Med. 2013, 19, 635-639. [CrossRef] 
58. Rothwell, N.J.; Stock, M.J. A role for brown adipose tissue in diet-induced thermogenesis. Nature 1979, 281, 31-35. [CrossRef]

59. Barrington, S.F.; Maisey, M.N. Skeletal muscle uptake of fluorine-18-FDG: Effect of oral diazepam. J. Nucl. Med. 1996, 37, 1127-1129. [PubMed]

60. Engel, H.; Steinert, H.; Buck, A.; Berthold, T.; Huch Böni, R.A.; von Schulthess, G.K. Whole-body PET: Physiological and artifactual fluorodeoxyglucose accumulations. J. Nucl. Med. 1996, 37, 441-446. [PubMed]

61. Enerbäck, S. Human brown adipose tissue. Cell Metab. 2010, 11, 248-252. [CrossRef]

62. Oelkrug, R.; Polymeropoulos, E.T.; Jastroch, M. Brown adipose tissue: Physiological function and evolutionary significance. J. Comp. Physiol. B 2015, 185, 587-606. [CrossRef]

63. Chusyd, D.E.; Wang, D.; Huffman, D.M.; Nagy, T.R. Relationships between Rodent White Adipose Fat Pads and Human White Adipose Fat Depots. Front. Nutr. 2016, 3, 10. [CrossRef] [PubMed]

64. Shabalina, I.G.; Petrovic, N.; de Jong, J.M.A.; Kalinovich, A.V.; Cannon, B.; Nedergaard, J. UCP1 in brite/beige adipose tissue mitochondria is functionally thermogenic. Cell Rep. 2013, 5, 1196-1203. [CrossRef]

65. Chondronikola, M.; Volpi, E.; Børsheim, E.; Porter, C.; Saraf, M.K.; Annamalai, P.; Yfanti, C.; Chao, T.; Wong, D.; Shinoda, K.; et al. Brown adipose tissue activation is linked to distinct systemic effects on lipid metabolism in humans. Cell Metab. 2016, 23, 1200-1206. [CrossRef]

66. Cederberg, A.; Grønning, L.M.; Ahrén, B.; Taskén, K.; Carlsson, P.; Enerbäck, S. FOXC2 is a winged helix gene that counteracts obesity, hypertriglyceridemia, and diet-induced insulin resistance. Cell 2001, 106, 563-573. [CrossRef]

67. Seale, P.; Conroe, H.M.; Estall, J.; Kajimura, S.; Frontini, A.; Ishibashi, J.; Cohen, P.; Cinti, S.; Spiegelman, B.M. Prdm16 determines the thermogenic program of subcutaneous white adipose tissue in mice. J. Clin. Investig. 2011, 121, 96-105. [CrossRef]

68. Zhang, Y.; Proenca, R.; Maffei, M.; Barone, M.; Leopold, L.; Friedman, J.M. Positional cloning of the mouse obese gene and its human homologue. Nature 1994, 372, 425-432. [CrossRef] [PubMed]

69. Scherer, P.E. Adipose tissue: From lipid storage compartment to endocrine organ. Diabetes 2006, 55, 1537-1545. [CrossRef]

70. Ahima, R.S.; Flier, J.S. Adipose tissue as an endocrine organ. Trends Endocrinol. Metab. 2000, 11, 327-332. [CrossRef]

71. Ahima, R.S.; Prabakaran, D.; Mantzoros, C.; Qu, D.; Lowell, B.; Maratos-Flier, E.; Flier, J.S. Role of leptin in the neuroendocrine response to fasting. Nature 1996, 382, 250-252. [CrossRef]

72. Scherer, P.E.; Williams, S.; Fogliano, M.; Baldini, G.; Lodish, H.F. A novel serum protein similar to C1q, produced exclusively in adipocytes. J. Biol. Chem. 1995, 270, 26746-26749. [CrossRef]

73. Stern, J.H.; Rutkowski, J.M.; Scherer, P.E. Adiponectin, leptin, and fatty acids in the maintenance of metabolic homeostasis through adipose tissue crosstalk. Cell Metab. 2016, 23, 770-784. [CrossRef]

74. Villarroya, F.; Cereijo, R.; Villarroya, J.; Giralt, M. Brown adipose tissue as a secretory organ. Nat. Rev. Endocrinol. 2016, 13, 26. [CrossRef]

75. Hondares, E.; Iglesias, R.; Giralt, A.; Gonzalez, F.J.; Giralt, M.; Mampel, T.; Villarroya, F. Thermogenic activation induces FGF21 expression and release in brown adipose tissue. J. Biol. Chem. 2011, 286, 12983-12990. [CrossRef] [PubMed]

76. Wang, G.-X.; Zhao, X.-Y.; Meng, Z.-X.; Kern, M.; Dietrich, A.; Chen, Z.; Cozacov, Z.; Zhou, D.; Okunade, A.L.; $\mathrm{Su}, \mathrm{X}$; et al. The brown fat-enriched secreted factor Nrg4 preserves metabolic homeostasis through attenuation of hepatic lipogenesis. Nat. Med. 2014, 20, 1436. [CrossRef]

77. Zhu, Z.; Spicer, E.G.; Gavini, C.K.; Goudjo-Ako, A.J.; Novak, C.M.; Shi, H. Enhanced sympathetic activity in mice with brown adipose tissue transplantation (transBATation). Physiol. Behav. 2014, 125, 21-29. [CrossRef] [PubMed]

78. Gunawardana, S.C.; Piston, D.W. Reversal of type 1 diabetes in mice by brown adipose tissue transplant. Diabetes 2012, 61, 674-682. [CrossRef] [PubMed]

79. Liu, X.; Zheng, Z.; Zhu, X.; Meng, M.; Li, L.; Shen, Y.; Chi, Q.; Wang, D.; Zhang, Z.; Li, C.; et al. Brown adipose tissue transplantation improves whole-body energy metabolism. Cell Res. 2013, 23, 851-854. [CrossRef] [PubMed]

80. Stanford, K.I.; Middelbeek, R.J.W.; Townsend, K.L.; An, D.; Nygaard, E.B.; Hitchcox, K.M.; Markan, K.R.; Nakano, K.; Hirshman, M.F.; Tseng, Y.-H.; et al. Brown adipose tissue regulates glucose homeostasis and insulin sensitivity. J. Clin. Investig. 2013, 123, 215-223. [CrossRef] [PubMed] 
81. Chen, Z.; Wang, G.-X.; Ma, S.L.; Jung, D.Y.; Ha, H.; Altamimi, T.; Zhao, X.-Y.; Guo, L.; Zhang, P.; Hu, C.-R.; et al. Nrg4 promotes fuel oxidation and a healthy adipokine profile to ameliorate diet-induced metabolic disorders. Mol. Metab. 2017, 6, 863-872. [CrossRef] [PubMed]

82. Furness, J.B. The organisation of the autonomic nervous system: Peripheral connections. Auton. Neurosci. 2006, 130, 1-5. [CrossRef] [PubMed]

83. Peterson, H.R.; Rothschild, M.; Weinberg, C.R.; Fell, R.D.; McLeish, K.R.; Pfeifer, M.A. Body fat and the activity of the autonomic nervous system. N. Engl. J. Med. 1988, 318, 1077-1083. [CrossRef]

84. Straznicky, N.E.; Lambert, G.W.; Masuo, K.; Dawood, T.; Eikelis, N.; Nestel, P.J.; McGrane, M.T.; Mariani, J.A.; Socratous, F.; Chopra, R.; et al. Blunted sympathetic neural response to oral glucose in obese subjects with the insulin-resistant metabolic syndrome. Am. J. Clin. Nutr. 2009, 89, 27-36. [CrossRef]

85. Jabbour, G.; Lemoine-Morel, S.; Casazza, G.A.; Hala, Y.; Moussa, E.; Zouhal, H. Catecholamine response to exercise in obese, overweight, and lean adolescent boys. Med. Sci. Sports Exerc. 2011, 43, 408-415. [CrossRef]

86. Spraul, M.; Ravussin, E.; Fontvieille, A.M.; Rising, R.; Larson, D.E.; Anderson, E.A. Reduced sympathetic nervous activity. A potential mechanism predisposing to body weight gain. J. Clin. Investig. 1993, 92, 1730-1735. [CrossRef]

87. Dogiel, A.S. Die sensiblen Nervenendigungen im Herzen und in den Blutgefässen der Säugethiere. Arch. Mikroskopische Anat. 1898, 52, 44-70. [CrossRef]

88. Sidman, R.L.; Fawcett, D.W. The effect of peripheral nerve section on some metabolic responses of brown adipose tissue in mice. Anat. Rec. 1954, 118, 487-507. [CrossRef] [PubMed]

89. WirsÉN, C. Adrenergic innervation of adipose tissue examined by fluorescence microscopy. Nature 1964, 202, 913. [CrossRef]

90. Bargmann, W.; Hehn, G.V.; Lindner, E. Über die Zellen des braunen Fettgewebes und ihre Innervation. Z. Zellforsch. Mikroskopische Anat. 1968, 85, 601-613. [CrossRef]

91. Giordano, A.; Morroni, M.; Santone, G.; Marchesi, G.F.; Cinti, S. Tyrosine hydroxylase, neuropeptide Y, substance $\mathrm{P}$, calcitonin gene-related peptide and vasoactive intestinal peptide in nerves of rat periovarian adipose tissue: An immunohistochemical and ultrastructural investigation. J. Neurocytol. 1996, 25, 125-136. [CrossRef] [PubMed]

92. Youngstrom, T.G.; Bartness, T.J. Catecholaminergic innervation of white adipose tissue in Siberian hamsters. Am. J. Physiol. Regul. Integr. Comp. Physiol. 1995, 268, R744-R751. [CrossRef] [PubMed]

93. Shi, H.; Demas, G. Special issue dedicated to Dr. Timothy J Bartness. Physiol. Behav. 2018, 190, 1-2. [CrossRef]

94. Bamshad, M.; Aoki, V.T.; Adkison, M.G.; Warren, W.S.; Bartness, T.J. Central nervous system origins of the sympathetic nervous system outflow to white adipose tissue. Am. J. Physiol. 1998, 275, R291-R299. [CrossRef]

95. Bamshad, M.; Song, C.K.; Bartness, T.J. CNS origins of the sympathetic nervous system outflow to brown adipose tissue. Am. J. Physiol. 1999, 276, R1569-R1578. [CrossRef]

96. Enquist, L.W. Exploiting circuit-specific spread of pseudorabies virus in the central nervous system: Insights to pathogenesis and circuit tracers. J. Infect. Dis. 2002, 186, S209-S214. [CrossRef]

97. Shi, H.; Bartness, T.J. Neurochemical phenotype of sympathetic nervous system outflow from brain to white fat. Brain Res. Bull. 2001, 54, 375-385. [CrossRef]

98. Nguyen, N.L.T.; Barr, C.L.; Ryu, V.; Cao, Q.; Xue, B.; Bartness, T.J. Separate and shared sympathetic outflow to white and brown fat coordinately regulates thermoregulation and beige adipocyte recruitment. Am. J. Physiol. Regul. Integr. Comp. Physiol. 2017, 312, R132-R145. [CrossRef]

99. Foster, M.T.; Bartness, T.J. Sympathetic but not sensory denervation stimulates white adipocyte proliferation. Am. J. Physiol. Regul. Integr. Comp. Physiol. 2006, 291, R1630-R1637. [CrossRef]

100. Shi, H.; Song, C.K.; Giordano, A.; Cinti, S.; Bartness, T.J. Sensory or sympathetic white adipose tissue denervation differentially affects depot growth and cellularity. Am. J. Physiol. Regul. Integr. Comp. Physiol. 2005, 288, R1028-R1037. [CrossRef]

101. Murano, I.; Barbatelli, G.; Giordano, A.; Cinti, S. Noradrenergic parenchymal nerve fiber branching after cold acclimatisation correlates with brown adipocyte density in mouse adipose organ. J. Anat. 2009, 214, 171-178. [CrossRef]

102. Jeong, J.H.; Chang, J.S.; Jo, Y.-H. Intracellular glycolysis in brown adipose tissue is essential for optogenetically induced nonshivering thermogenesis in mice. Sci. Rep. 2018, 8, 6672. [CrossRef] 
103. Brito, N.A.; Brito, M.N.; Bartness, T.J. Differential sympathetic drive to adipose tissues after food deprivation, cold exposure or glucoprivation. Am. J. Physiol. Regul. Integr. Comp. Physiol. 2008, 294, R1445-R1452. [CrossRef] [PubMed]

104. Vitali, A.; Murano, I.; Zingaretti, M.C.; Frontini, A.; Ricquier, D.; Cinti, S. The adipose organ of obesity-prone C57BL/6J mice is composed of mixed white and brown adipocytes. J. Lipid Res. 2012, 53, 619-629. [CrossRef] [PubMed]

105. Cinti, S. The adipose organ. Prostaglandins Leukot. Essent. Fatty Acids 2005, 73, 9-15. [CrossRef]

106. Fishman, R.B.; Dark, J. Sensory innervation of white adipose tissue. Am. J. Physiol. 1987, 253, R942-R944. [CrossRef] [PubMed]

107. Song, C.K.; Schwartz, G.J.; Bartness, T.J. Anterograde transneuronal viral tract tracing reveals central sensory circuits from white adipose tissue. Am. J. Physiol. Regul. Integr. Comp. Physiol. 2009, 296, R501-R511. [CrossRef]

108. Ryu, V.; Garretson, J.T.; Liu, Y.; Vaughan, C.H.; Bartness, T.J. Brown adipose tissue has sympathetic-sensory feedback circuits. J. Neurosci. 2015, 35, 2181-2190. [CrossRef] [PubMed]

109. Bartness, T.J.; Shrestha, Y.B.; Vaughan, C.H.; Schwartz, G.J.; Song, C.K. Sensory and sympathetic nervous system control of white adipose tissue lipolysis. Mol. Cell Endocrinol. 2010, 318, 34-43. [CrossRef]

110. Shi, H.; Bartness, T.J. White adipose tissue sensory nerve denervation mimics lipectomy-induced compensatory increases in adiposity. Am. J. Physiol. Regul. Integr. Comp. Physiol. 2005, 289, R514-R520. [CrossRef] [PubMed]

111. Bartness, T.J.; Vaughan, C.H.; Song, C.K. Sympathetic and sensory innervation of brown adipose tissue. Int. J. Obes. 2010, 34, S36-S42. [CrossRef]

112. Kreier, F.; Fliers, E.; Voshol, P.J.; Van Eden, C.G.; Havekes, L.M.; Kalsbeek, A.; Van Heijningen, C.L.; Sluiter, A.A.; Mettenleiter, T.C.; Romijn, J.A.; et al. Selective parasympathetic innervation of subcutaneous and intra-abdominal fat-Functional implications. J. Clin. Investig. 2002, 110, 1243-1250. [CrossRef] [PubMed]

113. Giordano, A.; Song, C.K.; Bowers, R.R.; Ehlen, J.C.; Frontini, A.; Cinti, S.; Bartness, T.J. White adipose tissue lacks significant vagal innervation and immunohistochemical evidence of parasympathetic innervation. Am. J. Physiol. Regul. Integr. Comp. Physiol. 2006, 291, R1243-R1255. [CrossRef] [PubMed]

114. Berthoud, H.-R.; Fox, E.A.; Neuhuber, W.L. Vagaries of adipose tissue innervation. Am. J. Physiol. Regul. Integr. Comp. Physiol. 2006, 291, R1240-R1242. [CrossRef] [PubMed]

115. Kreier, F.; Buijs, R.M. Evidence for parasympathetic innervation of white adipose tissue, clearing up some vagaries. Am. J. Physiol. Regul. Integr. Comp. Physiol. 2007, 293, R548-R549. [CrossRef] [PubMed]

116. Berthoud, H.-R.; Fox, E.A.; Neuhuber, W.L. Rebuttal: Controversial white adipose tissue innervation by the vagus nerve: Seeing is believing. Am. J. Physiol. Regul. Integr. Comp. Physiol. 2007, 293, R553-R554. [CrossRef]

117. Giordano, A.; Song, C.K.; Bowers, R.R.; Ehlen, J.C.; Frontini, A.; Cinti, S.; Bartness, T.J. Reply to Kreier and Buijs: No sympathy for the claim of parasympathetic innervation of white adipose tissue. Am. J. Physiol. Regul. Integr. Comp. Physiol. 2007, 293, R550-R552. [CrossRef]

118. Chi, J.; Wu, Z.; Choi, C.H.J.; Nguyen, L.; Tegegne, S.; Ackerman, S.E.; Crane, A.; Marchildon, F.; Tessier-Lavigne, M.; Cohen, P. Three-dimensional adipose tissue imaging reveals regional variation in beige fat biogenesis and PRDM16-dependent sympathetic neurite density. Cell Metab. 2018, 27, 226-236. [CrossRef]

119. Chi, J.; Crane, A.; Wu, Z.; Cohen, P. Adipo-Clear: A tissue clearing method for three-dimensional imaging of adipose tissue. J. Vis. Exp. 2018, 137, e58271. [CrossRef] [PubMed]

120. Blaszkiewicz, M.; Willows, J.W.; Dubois, A.L.; Waible, S.; Johnson, C.P.; DiBello, K.; Lyons, L.L.; Breeding, W.P.; Tilbury, K.B.; Michael, M.; et al. Neuropathy and neural plasticity in the subcutaneous white adipose depot. bioRxiv 2018, 480095. [CrossRef]

121. Jiang, H.; Ding, X.; Cao, Y.; Wang, H.; Zeng, W. Dense intra-adipose sympathetic arborizations are essential for cold-induced beiging of mouse white adipose tissue. Cell Metab. 2017, 26, 686-692. [CrossRef]

122. Murphy, K.T.; Schwartz, G.J.; Nguyen, N.L.T.; Mendez, J.M.; Ryu, V.; Bartness, T.J. Leptin-sensitive sensory nerves innervate white fat. Am. J. Physiol. Endocrinol. Metab. 2013, 304, E1338-E1347. [CrossRef]

123. Garretson, J.T.; Szymanski, L.A.; Schwartz, G.J.; Xue, B.; Ryu, V.; Bartness, T.J. Lipolysis sensation by white fat afferent nerves triggers brown fat thermogenesis. Mol. Metab. 2016, 5, 626-634. [CrossRef] [PubMed] 
124. Bartness, T.J.; Bamshad, M. Innervation of mammalian white adipose tissue: Implications for the regulation of total body fat. Am. J. Physiol. Regul. Integr. Comp. Physiol. 1998, 275, R1399-R1411. [CrossRef] [PubMed]

125. Lafontan, M.; Bousquet-Melou, A.; Galitzky, J.; Barbe, P.; Carpéné, C.; Langin, D.; Berlan, M.; Valet, P.; Castan, I.; Bouloumié, A.; et al. Adrenergic receptors and fat cells: Differential recruitment by physiological amines and homologous regulation. Obes. Res. 1995, 3, 507S-514S. [CrossRef] [PubMed]

126. Brasaemle, D.L. Thematic review series: Adipocyte Biology. The perilipin family of structural lipid droplet proteins: Stabilization of lipid droplets and control of lipolysis. J. Lipid Res. 2007, 48, 2547-2559. [CrossRef]

127. Yoshitomi, H.; Yamazaki, K.; Abe, S.; Tanaka, I. Differential regulation of mouse uncoupling proteins among brown adipose tissue, white adipose tissue, and skeletal muscle in chronic beta 3 adrenergic receptor agonist treatment. Biochem. Biophys. Res. Commun. 1998, 253, 85-91. [CrossRef] [PubMed]

128. Bowers, R.R.; Festuccia, W.T.L.; Song, C.K.; Shi, H.; Migliorini, R.H.; Bartness, T.J. Sympathetic innervation of white adipose tissue and its regulation of fat cell number. Am. J. Physiol. Regul. Integr. Comp. Physiol. 2004, 286, R1167-R1175. [CrossRef] [PubMed]

129. Hsieh, A.C.L.; Carlson, L.D. Role of adrenaline and noradrenaline in chemical regulation of heat production. Am. J. Physiol. 1957, 190, 243-246. [CrossRef]

130. Depocas, F. The calorigenic response of cold-acclimated white rats to infused noradrenaline. Can. J. Biochem. Physiol. 1960, 38, 107-114. [CrossRef] [PubMed]

131. Young, J.B.; Saville, E.; Rothwell, N.J.; Stock, M.J.; Landsberg, L. Effect of diet and cold exposure on norepinephrine turnover in brown adipose tissue of the rat. J. Clin. Investig. 1982, 69, 1061-1071. [CrossRef] [PubMed]

132. Morrison, S.F.; Madden, C.J.; Tupone, D. Central neural regulation of brown adipose tissue thermogenesis and energy expenditure. Cell Metab. 2014, 19, 741-756. [CrossRef]

133. Enerback, S.; Jacobsson, A.; Simpson, E.M.; Guerra, C.; Yamashita, H.; Harper, M.-E.; Kozak, L.P. Mice lacking mitochondrial uncoupling protein are cold-sensitive but not obese. Nature 1997, 387, 90-94. [CrossRef]

134. Maickel, R.P.; Matussek, N.; Stern, D.N.; Brodie, B.B. The sympathetic nervous system as a homeostatic mechanism. I. Absolute need for sympathetic nervous function in body temperature maintenance of cold-exposed rats. J. Pharmacol. Exp. Ther. 1967, 157, 103-110.

135. Nakayama, A.; Bianco, A.C.; Zhang, C.-Y.; Lowell, B.B.; Frangioni, J.V. Quantitation of brown adipose tissue perfusion in transgenic mice using near-infrared fluorescence imaging. Mol. Imaging 2003, 2, 37-49. [CrossRef]

136. Montanari, T.; Pošćić, N.; Colitti, M. Factors involved in white-to-brown adipose tissue conversion and in thermogenesis: A review. Obes. Rev. 2017, 18, 495-513. [CrossRef]

137. Gregoire, F.M.; Smas, C.M.; Sul, H.S. Understanding adipocyte differentiation. Physiol. Rev. 1998, 78, $783-809$. [CrossRef]

138. Kajimura, S.; Seale, P.; Kubota, K.; Lunsford, E.; Frangioni, J.V.; Gygi, S.P.; Spiegelman, B.M. Initiation of myoblast to brown fat switch by a PRDM16-C/EBP- $\beta$ transcriptional complex. Nature 2009, 460, 1154. [CrossRef] [PubMed]

139. Fukunaka, A.; Fukada, T.; Bhin, J.; Suzuki, L.; Tsuzuki, T.; Takamine, Y.; Bin, B.-H.; Yoshihara, T.; Ichinoseki-Sekine, N.; Naito, H.; et al. Zinc transporter ZIP13 suppresses beige adipocyte biogenesis and energy expenditure by regulating C/EBP- $\beta$ expression. PLOS Genet. 2017, 13, e1006950. [CrossRef] [PubMed]

140. Rosen, E.D.; Sarraf, P.; Troy, A.E.; Bradwin, G.; Moore, K.; Milstone, D.S.; Spiegelman, B.M.; Mortensen, R.M. PPAR gamma is required for the differentiation of adipose tissue in vivo and in vitro. Mol. Cell 1999, 4, 611-617. [CrossRef]

141. Karamanlidis, G.; Karamitri, A.; Docherty, K.; Hazlerigg, D.G.; Lomax, M.A. C/EBP $\beta$ reprograms white 3T3-L1 preadipocytes to a brown adipocyte pattern of gene expression. J. Biol. Chem. 2007, 282, 24660-24669. [CrossRef]

142. Giralt, M.; Villarroya, F. White, brown, beige/brite: Different adipose cells for different functions? Endocrinology 2013, 154, 2992-3000. [CrossRef]

143. Migliorini, R.H.; Garofalo, M.A.; Kettelhut, I.C. Increased sympathetic activity in rat white adipose tissue during prolonged fasting. Am. J. Physiol. 1997, 272, R656-R661. [CrossRef]

144. Shi, H.; Akunuru, S.; Bierman, J.C.; Hodge, K.M.; Mitchell, M.C.; Foster, M.T.; Seeley, R.J.; Reizes, O. Diet-induced obese mice are leptin insufficient after weight reduction. Obesity 2009, 17, 1702-1709. [CrossRef] 
145. Garofalo, M.A.; Kettelhut, I.C.; Roselino, J.E.; Migliorini, R.H. Effect of acute cold exposure on norepinephrine turnover rates in rat white adipose tissue. J. Auton. Nerv. Syst. 1996, 60, 206-208. [CrossRef]

146. Labbé, S.M.; Caron, A.; Chechi, K.; Laplante, M.; Lecomte, R.; Richard, D. Metabolic activity of brown, "beige," and white adipose tissues in response to chronic adrenergic stimulation in male mice. Am. J. Physiol. Endocrinol. Metab. 2016, 311, E260-E268. [CrossRef] [PubMed]

147. Kalsbeek, A.; Bruinstroop, E.; Yi, C.X.; Klieverik, L.P.; La Fleur, S.E.; Fliers, E. Hypothalamic control of energy metabolism via the autonomic nervous system. Ann. N. Y. Acad. Sci. 2010, 1212, 114-129. [CrossRef] [PubMed]

148. Ryu, V.; Watts, A.G.; Xue, B.; Bartness, T.J. Bidirectional crosstalk between the sensory and sympathetic motor systems innervating brown and white adipose tissue in male Siberian hamsters. Am. J. Physiol. Regul. Integr. Comp. Physiol. 2017, 312, R324-R337. [CrossRef]

149. Harris, R.B.S. Denervation as a tool for testing sympathetic control of white adipose tissue. Physiol. Behav. 2018, 190, 3-10. [CrossRef]

150. Cousin, B.; Casteilla, L.; Lafontan, M.; Ambid, L.; Langin, D.; Berthault, M.F.; Pénicaud, L. Local sympathetic denervation of white adipose tissue in rats induces preadipocyte proliferation without noticeable changes in metabolism. Endocrinology 1993, 133, 2255-2262. [CrossRef]

151. Townsend, K.L.; Madden, C.J.; Blaszkiewicz, M.; McDougall, L.; Tupone, D.; Lynes, M.D.; Mishina, Y.; Yu, P.; Morrison, S.F.; Tseng, Y.-H. Reestablishment of energy balance in a male mouse model with POMC neuron deletion of BMPR1A. Endocrinology 2017, 158, 4233-4245. [CrossRef]

152. Klingenspor, M.; Meywirth, A.; Stöhr, S.; Heldmaier, G. Effect of unilateral surgical denervation of brown adipose tissue on uncoupling protein mRNA level and cytochrom-c-oxidase activity in the Djungarian hamster. J. Comp. Physiol. B 1994, 163, 664-670. [CrossRef]

153. Dulloo, A.G.; Miller, D.S. Energy balance following sympathetic denervation of brown adipose tissue. Can. J. Physiol. Pharmacol. 1984, 62, 235-240. [CrossRef] [PubMed]

154. Thoenen, H.; Tranzer, J.P.; Häusler, G. Chemical Sympathectomy with 6-Hydroxydopamine; Springer: Berlin, Germany, 1970; Volume 2, pp. 130-143.

155. Himms-Hagen, J.; Cui, J.; Lynn Sigurdson, S. Sympathetic and sensory nerves in control of growth of brown adipose tissue: Effects of denervation and of capsaicin. Neurochem. Int. 1990, 17, 271-279. [CrossRef]

156. Jin, Y.; Fan, J.; Li, F.; Bi, L.; Pei, G. Local sympathetic denervation of femoral artery in a rabbit model by using 6-hydroxydopamine in situ. Biomed. Res. Int. 2014, 2014, 874947. [CrossRef] [PubMed]

157. Vaughan, C.H.; Bartness, T.J. Anterograde transneuronal viral tract tracing reveals central sensory circuits from brown fat and sensory denervation alters its thermogenic responses. Am. J. Physiol. Regul. Integr. Comp. Physiol. 2012, 302, R1049-R1058. [CrossRef] 